\title{
Modelling the continuous innovation capability enablers in Indonesia's manufacturing industry
}

Continuous innovation capability enablers

\author{
Benny Lianto and Muhammad Dachyar \\ Department of Industrial Engineering, Universitas Indonesia, Depok, \\ Indonesia, and \\ Tresna Priyana Soemardi \\ Department of Mechanical Engineering, Universitas Indonesia, Depok, Indonesia
}

Received 11 April 2020

\begin{abstract}
Purpose - The purpose of this paper is to identify and screen continuous innovation capability enablers (CICEs) in Indonesia's manufacturing sectors, develop a relationship among these enablers and determine their driving power and dependence power in the sector.

Design/methodology/approach - The initial CICEs identification process is based on a literature review, while a fuzzy Delphi method (FDM) was used for the screening process of CICEs. Total interpretive structural modelling (TISM) was used to develop contextual relationships among various CICEs. The results of the TISM are used as an input for the matrix of cross-impact multiplications applied to classification (MICMAC) to classify the driving power and dependence powers of the CICEs.

Findings - This paper selected 16 CICEs classified in seven dimensions. TISM results and MICMAC analysis show that leadership, as well as climate and culture, are enablers with the highest driving power and lowest dependence powers; followed by information technology. The results of this study indicate that efforts to continuously develop innovation capabilities in the Indonesian manufacturing industries are strongly influenced by their leadership capability, climate and culture, also information technology-related capability.

Practical implications - The framework assessed in this study provides business managers and policymakers to obtain a bigger picture in developing policies with evidence-based strategy and priority in regard to continuous innovation capability.

Originality/value - The results will be useful for business managers and policymakers to understand the relationship between CICEs and identify key CICEs in Indonesia's manufacturing sectors, which were previously non-existent.
\end{abstract}

Keywords Innovation, Manufacturing, Fuzzy, Expert systems, Modelling, Innovation enablers, Continuous innovation capability, Indonesia

Paper type Research paper

\section{Introduction}

The manufacturing sectors can be analysed from different perspectives depending on what information is being sought. This is because manufacturing sectors in the Asia Pacific are diverse and consist of many sectors, covering a wide range of perspectives from energy efficiency (Foumani and Smith-Miles, 2019) to automation (Foumani et al., 2020). The perspective of this study specifically is concentrated on Continuous Innovation (CI) as it has been widely proven as one of the key factors for a company's competitiveness and success in

The authors would like to thank University of Surabaya (UBAYA) for permits and support this research funding.

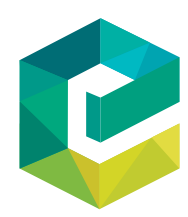

Journal of Modelling in Management (c) Emerald Publishing Limited $1746-5664$ 
the ever-changing and dynamic business and industries environment (Steiber and Alänge, 2013; Javahernia and Sunmola, 2017; Stålberg, 2018; Lianto et al., 2018). Rothaermel and Hess (2010) stated that CI is the engine driving highly successful companies such as Apple, Google, Honda, Hewlett-Packard, Microsoft, General Electric, P\&G, Sony and Tata Group. Hyland and Boer (2006) defines CI as the fundamental task for an organization that exists in dynamic and unstable environments and it requires constant surveillance of regulatory policies, technologies and the capability to quickly accomplish changes while being and staying successful in the market place at the same time, all the time. CI is also referred to as the ability to continuously innovate and renew an organization to develop new products and business models (Steiber and Alänge, 2013).

Given the importance of continuous innovation, many companies, including the ones in Indonesia's manufacturing industry, strive to manage their innovation activities effectively and sustainably as a means of preparation to enter the very dynamic business environment in the Fourth Industrial Revolution. Hence, companies need to have a model or methodology to monitor their continuous innovation capability (CIC) to ensure innovation activities in the company are performed continuously in a timely and sustainable manner (Steiber and Alänge, 2013). The models are needed to identify ways to stay innovative sustainably, in the long term.

Previously, CIC has been studied from various setting and various enablers, called their continuous innovation capability enablers (CICEs), have been identified (Joshi et al., 2010; Steiber and Alänge, 2013; Steiber, 2014; Ab Rahman et al., 2015; Chen, 2016). However, the effort to formulate contextual relationships between CICEs and to determine the driving power and dependence power of each enabler is still limited, particularly for Indonesia's manufacturing industry. Thorough understanding of prominent CICEs, their relationship patterns, as well as driving power and dependence power is much needed because they will provide insights to academic experts, industry practitioners and the government on which crucial enablers needed the most to develop sustainable CI capability. Dewangan and Godse (2014) mentioned that a holistic understanding of the system of innovation capability and performance must be able to show cause and effect relationship between measured factors or elements.

The purpose of this paper is to fill the gap in determining contextual CICEs in the manufacturing industry in Indonesia, to investigate the contextual relationships between selected CICEs and to determine their driving power and dependence power. The paper will provide insights to industry managers and practitioners on how to effectively manage the innovation process and to obtain a proper macro picture analyzing the relationship between CICEs - as to assist them in selecting strategic CICEs to focus on.

The paper is structured as follows: firstly, the selection of previous research on CI, CIC and CICEs will be made available, the review focuses more on factors relevant to the manufacturing industry and particularly for the Indonesian context. Secondly, the method for this study will be presented: selection process for CICEs was performed by using the fuzzy Delphi method (FDM) approach, with a panel of industry practitioners and academic experts, followed by drawing a contextual relationship between CICEs using total interpretive structural modelling (TISM) model involving a panel of experts from Indonesian manufacturing associations and by determining driving power and dependence power of CICEs using the matrix of cross-impact multiplications applied to classification (MICMAC). Fourth, the research result and its subsequent implications will be discussed.

\section{Literature review}

Nowadays, with a very competitive business environment, innovation has become one of the most important sources of competitive advantage for many companies (Chutivongse and Gerdsri, 2018). However, in a very dynamic business environment, innovation performance 
is not sufficient. Javahernia and Sunmola (2017) implied that CI capability, that is the ability to continuously innovate, is needed by the manufacturing industry today so the industry can have high competitiveness and continue to survive; by continuously producing new products, new processes, new service systems and new business models that are always relevant to the needs. Xue in Chen (2016) explained three characteristics of CI, i.e. persistence, sustainable economic growth and sustainable development of enterprises. Based on those characteristics, $\mathrm{CI}$ is a process performed consistently in the long term, to achieve sustainable economic performance and development in a company. This concept is supported by Xiang and $\mathrm{Wu}$ (2012), they promoted the enterprise sustainable innovation concept - a long term process in which a company constantly introduces and implements new innovation projects and subsequently benefiting sustainably from the process.

$\mathrm{CI}$ is also defined as the ability of a company to renew the organization, to develop new products, new processes and new business models (Steiber and Alänge, 2013). Boer and Gertsen (2003) mentioned three essential elements of CI: continuous improvement, learning, dan innovation. Consistent and effective interaction between continuous improvement, learning, dan innovation will contribute significantly to sustainable innovation in an organization. Nisula and Kianto (2013) proposed a concept of organizational renewal capability, of which a company with constant renewal willingness and the process will have the advantage to properly develop, change, modify and organize resources, knowledge, assets and routines to boost its competitiveness.

In practice, $\mathrm{CI}$ is determined strongly by $\mathrm{CIC}$ - a set of fundamental elements and comprehensive characteristics in an organization required to facilitate and support innovation activities. This set consists of different capabilities, acting as assets and special resources within an organization in doing innovation activities. Determining factors for CICEs or so-called continuous innovation capability enablers, are complex and diverse (Boly et al., 2014; Saunila, 2017; Saunila and Ukko, 2012). Steiber and Alänge (2013) mentioned seven determining factors for CIC, i.e. culture, individuals, leaders, organization, P\&I system, learning and external interaction. The following year, Steiber (2014) proposed the Six Management Principles of Continuous Innovation, consisting of dynamic capabilities, a continuously changing organization, a people-centric approach, an ambidextrous organization, an open organization that networks with its surroundings, dan a systems approach. Colarelli O'Connor in Björkdahl and Börjesson (2012) stated that in a systemic approach for innovation activities in an organization, these factors are important: organizational structure, leadership, organizational culture, development of people skills, organizational governance and decision-making mechanism.

A number of CICEs relevant to the manufacturing industry are presented and explained in the following.

\subsection{Digital technology}

The role of digital technology, usually identified as a form of modern technology such as cloud, wearables, mobile, social media and business analytics, has been acknowledged in improving a company's innovation potential (Lokuge et al., 2019). Ferreira et al. (2019) mentioned that digital technology will open a big opportunity for a company to develop its innovation capability, particularly in this digital era. It will also allow companies to collaborate with other necessary parties but at a low capital intensity (Tan et al., 2016). Past research on manufacturing industries in various countries shows that digital technology influences the development of innovation capability (Oldham and Da Silva, 2015; Ravichandran, 2018).
Continuous innovation capability enablers 
Research and observation on manufacturing industries in various countries show that information technology (IT) capability influence the development of an innovation capability (Dong and Netten, 2017; Joshi et al., 2010; Benitez et al., 2017; Chen et al., 2015). Good IT capability will dispense data or information up/down to or from employees so a company can adapt fast to changes in the environment (Chae et al., 2018). Ben Moussa and El Arbi (2020) also concluded that investment in improving IT capability such as the implementation of the human resources information system, could improve individual innovation capability, particularly to enhance human resource creativity and the ability to find new approaches and solutions.

\subsection{Production technology}

Several studies found that the innovation capability of a company is determined by its ability to develop production technological capabilities (Afuah, 2002; Reichert et al., 2011). Production technology capability will support the development process and production of new products. A number of research on manufacturing industries in various countries also indicated production or manufacturing technology capability as the core indicators to evaluate continuous innovation capability (Chen, 2016). It also should be noted that one of the primary aspects of technology innovation capability is manufacturing capability, determined by the advanced manufacturing technology level of an organization (Wang et al., 2008). Production technology capability will also influence the innovation process strategy of a company to yield high-quality, flexible and efficient products - readily delivered to consumers in a precise and timely manner (Prajogo, 2016).

\subsection{Internal research and development}

Internal research and development have been recognized as an effective management strategy to facilitate firms' innovation (Zhang and Tang, 2017). Internal research and development (R\&D) capability will improve a company's ability to renew their technological knowledge, nurturing the company's ability to redesign products for ease of use, increasing the range of customized options, radical changes in product definition and open up to the new market (Kocoglu et al., 2012). A number of research on manufacturing industries clearly highlight the finding that R\&D capabilities are one of the key factors for innovation capability development, particularly for large-scale industries (Boly et al., 2014; Dong and Netten, 2017; Gkypali et al., 2017; Gu et al., 2016; Hsu et al., 2017; Rasiah et al., 2016).

\subsection{Adaptive capability}

The adaptive capability has been understood as abilities related to problem-solving and speedy responses to customers, responses to market customer opportunities, response to opportunities and speedy response in pursuing these opportunities (Wei and Lau, 2010). Employee's adaptive capability will increase their creativity in developing diverse products and processes in response to new opportunities. Several studies on CI capabilities in the manufacturing industries in various countries showed that adaptive capability influences the development of continuous innovation capability (Boly et al., 2014; Rangus and Slavec, 2017). Wiwoho et al. (2020) found that adaptive capability was positively related to product innovation. Another study by Ali et al. (2017) also highlighted a strong and significant relationship between adaptive capability and organizational innovation. They found that all dimensions of adaptive capability helped to develop and to improve the performance of organizational innovation. 


\subsection{Skill and education}

Employee's skill and education level are widely observed as one of the determining aspects for a company to develop its innovation capability (Kianto et al., 2017; Liu et al., 2017; Ben Moussa and El Arbi, 2020). Employees with higher skill and education levels tend to have a higher commitment, and thus can give more contributions to innovation performance. Mir-Babayev (2015) found that those employees would support a company in patent development to improve product innovation performance. These observations were also supported by various researchers, confirming that skill, education and talent influence the development of an innovation capability (Ceci and Iubatti, 2012; Steiber, 2014; Zeng et al., 2017).

\subsection{Motivation and participation}

Employees' motivation to be part of an innovation process is affected by multiple factors. The ability of an employee to make decisions and feel empowered is a significant factor in their motivation to participate in innovation processes (Palin and Kaartemo, 2016). The motivation resulted from support from the company's management will affect their participation level in the company's innovation activities (Fernandez and Pitts, 2011). In another study, it was found that encouragement and support from the company's side are key factors for employees to feel bound to innovate. Allen et al. (2015) mentioned that a proper human resource management approach contributed to increasing trust and consequently boost employee's motivation and participation in innovation processes. One fundamental principle found in companies with continuous innovation capabilities is that they are people-centric (Steiber, 2014). This finding is also supported by Banerjee (2014).

\subsection{Integrated strategy}

Several past studies discovered that the strategy dimension plays an important role in maximizing the capability of a company's innovation (Rohrbeck and Gemünden, 2011). A number of factors related to the dimension include strategic enablers (Sun et al., 2012), integrated strategy (Boly et al., 2014) and strategic competence (Nisula and Kianto, 2013; Mir et al., 2016). Aramburu and Sáenz's (2011) studies revealed that innovation strategy and the network had a significant influence on innovation capability. An innovation strategy facilitates an organization's ability to identify external opportunities and match those opportunities with internal capabilities so as to explore new markets and deliver innovative products (Wang and Ahmed, 2004).

\subsection{Dynamic capabilities}

Dynamic capabilities refer to how a firm uses resources to respond to or initiate market changes (Michailova and Zhan, 2015). Dynamic capabilities are also considered as strategic dimensions, describing the ability of a company to integrate, develop and reconfigure internal and external competencies to face rapid changes. There are three dynamic capability skills, namely, sensing and shaping opportunities/threats, seizing opportunities and maintaining competitiveness (Teece, 2007). Dynamic capabilities will play a role in a company's activities to harmonize and integrate various resources, to reconfigure resources and to create new knowledge routines, in which company leaders build up new resources and knowledge in developing innovation capabilities (Eisenhardt and Martin, 2000).

\subsection{Leadership}

The role of leadership in supporting innovation by creating a conducive environment has been established in the literature (Lawson and Samson, 2001; Saunila et al., 2014). 
Chang et al. (2015) stated that leadership is the key to facilitating innovation activities and tends to affect the success of companies in emerging countries. On the other hand, Xie et al. (2011) revealed that the style of leadership greatly influences the innovation atmosphere in a company and can facilitate trust and individuals' identification. Several studies on manufacturing industries in various countries showed that leadership capability greatly influences the development of an innovation capability (Delgado-Verde et al., 2011; Xie et al., 2018; Sun et al., 2012; Nisula and Kianto, 2013; Steiber and Alänge, 2013; Chang et al., 2015; Carreiro and Oliveira, 2019).

\subsection{Culture and climate}

Numerous studies have recognized organizational culture and climate as a driving force for innovation capability. Past research also showed that climate and culture determine the innovation performance of a company (Shahzad et al., 2017). A strong organizational culture tends to significantly stimulate the creativity and innovation behaviour of employees by creating formal rules and regulations with an open climate for employees to develop ideas and creativity (Naranjo-Valencia et al., 2016). Research on manufacturing industries in various countries indicated that the organization's culture and climate have a positive influence on innovation capability development (Sarros et al., 2008; Delgado-Verde et al., 2011; Steiber and Alänge, 2013; Boly et al., 2014).

\subsection{Organizational agility}

Organizational agility, defined as a company's ability to respond swiftly and innovatively to unexpected changes, has been widely recognized as an important capability to develop innovation in a company (Lu and Ramamurthy, 2011). Cai et al. (2017) stated that organizational agility will drive a company to be more sensitive to valuable market information and subsequently, act and make decisions for product innovation. Past research in manufacturing industries in various countries indicated that organizational agility has a positive influence on innovation capability development (Ravichandran, 2018; Rohrbeck and Gemünden, 2011; Wu et al., 2016).

\subsection{Project management skill}

Project management skill has been highlighted as one of the most important enablers of innovation capability (Guertler and Sick, 2020). The role of project management in supporting innovation activities and projects in a company has become increasingly significant. Kavanagh and Naughton (2009) found that the ability to develop and maintain innovation capability was determined by a company's ability to advance and preserve project management skills at world-class levels. Hernandez and Cormican (2016) proposed the need for a project management approach in social innovation-oriented projects. Ju et al. (2019) also mentioned that agile project management contributed to increasing a company's innovation capability. Research on innovation capabilities in various countries indicated that project management skills have a positive influence on innovation capability development (Boly et al., 2014; Mir et al., 2016; Zeng et al., 2017).

\subsection{Structure and system}

One of the six management principles proposed by Steiber (2014) is a continuously changing organization. This principle states that organizations need to continue to change and adapt to changing dynamic business and industrial environments. Conversely, Steiber and Alänge (2013) expressed that the organization structure and performance of an incentive system in 
an internal infrastructure is very important for the development of continuous innovation capabilities. Past research on innovation capabilities in various countries revealed that the organization's structure and system have a positive influence on its development (Chen et al., 2015; Palacios-Marqués et al., 2016; Rangus and Slavec, 2017; Zeng et al., 2017).

\subsection{Knowledge management capacity}

In a rapidly changing market, the knowledge dimension plays a central role in determining opportunities for innovation and company excellence (Dong and Netten, 2017; Dong et al., 2016). Knowledge is a key component in achieving long-term continuous innovation and has been widely accepted in modern management (Chapman and Magnusson, 2006). A study by Yusr et al. (2014) showed that the ability of the manufacturing industry to administer their knowledge management optimally will increase their innovation capability. Chapman and Hyland (2004) revealed that the capabilities of continuous innovation are closely associated with the knowledge management system and processes. A number of other studies on innovation capabilities in the manufacturing industry highlighted similar findings (Boly et al., 2014; Liu et al., 2017; Pérez-Luño et al., 2011; Santoro et al., 2018; Wang and Hu, 2017).

\subsection{Knowledge assets}

Knowledge assets are identified as one of the key organizational factors to support innovation development in a company (Delgado-Verde et al., 2011). The number and the quality of knowledge assets and their optimum utilization will contribute positively to innovation activities (Rupietta and Backes-Gellner, 2019). Management of knowledge assets, in the form of intellectual property rights, will also affect a company's innovation productivity (Allarakhia and Walsh, 2011). Past research on innovation capabilities in various countries revealed that knowledge assets have a positive influence on its development (Joshi et al., 2010; Delgado-Verde et al., 2011; Rupietta and Backes-Gellner, 2019)

\subsection{Organizational learning}

Learning has been emphasized as one of the most important enablers of innovation capability (Bessant et al., 2012). Xie et al. (2011) stated that continuous innovation capability could be formed through continuous learning and renewal process to achieve a selfsustaining and self-reinforcing state. The learning process will bridge the working process and innovation process (Iddris, 2016). It is recommended that lifelong learning, management support and risk tolerance should be encouraged to improve creativity. A high level of creativity is important in enhancing the capacity to integrate internal and external knowledge for greater levels of organizational learning. Further research should be carried out to find how customers' and suppliers' information can be used to enriched organizational learning (Gachanja et al., 2020). It has been recorded that organizational learning capability influenced the development of innovation capability (Boly et al., 2014; Chen, 2016; Nisula and Kianto, 2013).

\subsection{Inter-firm collaboration}

Numerous empirical studies have confirmed that innovation is influenced by social interactions and social networks (Gonzalez-Brambila et al., 2013; Guan and Liu, 2016). In this digital and enhanced connectivity era, companies have the advantage and opportunity to develop collaborative innovation networks and to work on innovations collectively. This circumstance drove the emergence of a new innovation strategy called Open Innovation (OI).
Continuous innovation capability enablers

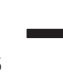


With OI, the innovation performance of a company is no longer dependent on internal knowledge and technology but also needs to be completed with external knowledge obtained from the company's ability to form linkages with external parties. Numerous studies on the innovation capabilities of the manufacturing industries in various countries showed that several factors related to inter-firm collaboration have a significant effect on the development of innovation capabilities: cooperative networks (Gu et al., 2016), collaboration innovation activities (Wang and Hu, 2017), open innovation (Santoro et al., 2018), connectivity (Nisula and Kianto, 2013), external interaction (Steiber and Alänge, 2013), social capital (Pérez-Luño et al., 2011), informal social interaction (Liu et al., 2017), collaboration (Walsh et al., 2016) and customer input (Gu et al., 2016).

\subsection{Intra-firm collaboration}

Innovation is a collective and social activity. Bittner and Heidemeier (2013) found that employees' innovation activities will increase when being supported by a collaborative environment within a company. If a collaborative culture between employees and departments in a company are nurtured well, they will be more comfortable and supportive in sharing and discussing to develop new ideas. Zhang and Tang (2017) stated that extensive intra-firm collaboration may promote the flow of diversified knowledge and bring forth novel knowledge combination to facilitate the faster formation of innovation capability. Past studies on the innovation capabilities of the manufacturing industries in various countries mentioned several factors of intra-firm collaboration necessary to drive innovation capability: internal collaboration (Zhang and Tang, 2017), intra-organizational control (Liu et al., 2017), intra-organizational social capital (Maurer et al., 2011), online social networks (Palacios-Marqués et al., 2016) and integration between functions (Zeng et al., 2017).

\subsection{Internal financing capabilities}

Research on the impact of internal financing capabilities on innovation activities in a company has been widely published. Abdu and Jibir (2018) found that the financing capability of a company is a crucial factor affecting innovation capability. A study on companies in 9 African countries revealed that limitation in the financing capability of a company negatively affected innovation capability (Lorenz, 2014). Based on input from manufacturing industry practitioners in Indonesia, this research will follow the hypothesis constructed by Efthyvoulou and Vahter (2013), that the effect of financial constraints on innovation activities or capability of a company might differ according to the company's characteristics and sectors.

\subsection{Access to external financing}

Studies on a company's ability to have access to external financing and its effect on the degree of innovation have been conducted in the past (Abdu and Jibir, 2018; Efthyvoulou and Vahter, 2013; Kou et al., 2020; Nylund et al., 2019). The capability of access to external financing such as the capability to obtain concessional loans will aid the company in performing innovation activities. If the reverse were to occur, innovation activities are hindered (Nylund et al., 2019).

\section{Methodology and model development}

The research process consists of the following four stages, as shown in Figure 1. 


\subsection{Identification of initial continuous innovation capability enablers}

The process of identifying the initial CICEs was performed in two stages. In the first stage, initial CICEs were identified using a literature review approach, which was then confirmed by manufacturing industry practitioners using the focus group discussion (FGD) approach. This FGD was conducted to ensure that CICEs identified from the results of the literature review were contextually relevant to current conditions experienced by manufacturing industries in Indonesia. The initial CICEs were further grouped into seven dimensions, consisting of six dimensions of continuous innovation development strategies based on conformity (Lianto et al., 2018), namely, technology, people, strategy, organization, knowledge management, collaboration; and one dimension from the industry practitioners' input, i.e. the financial dimension.

\subsection{Screening of continuous innovation capability enablers}

The screening process for initial CICEs was carried out using FDM; which is an analytical method based on the Delphi and fuzzy theory. FDM is a collaborative decision-making method, which involves experts and has been used extensively in various fields (Cho and Lee, 2013; Hsu et al., 2017; Tahriri et al., 2014). In the screening process for the CICEs, the Fuzzy Delphi method (Hsu et al., 2010) is used to show the consensus of the experts using the geometric mean approach. The FDM steps are as follows:

3.2.1 Collection of experts' opinions. This step was conducted using a questionnaire, consisting of two parts. The first contains questions related to the experts' general data and profiles. The second contains questions on the level of importance of 18 initial CICEs; the importance weights are calculated using linguistic terms (one to seven-point scale) and a fuzzy scale (Table 1 ).

The panel of experts comprising industry experts and academic experts (scholars). The selection of experts was carried out based on their knowledge and skills (Hsu et al., 2017) as shown in Table 2. Practitioners in this study also came from reputable manufacturing industries with a long history and were included in the Forbes Indonesia Best Award in

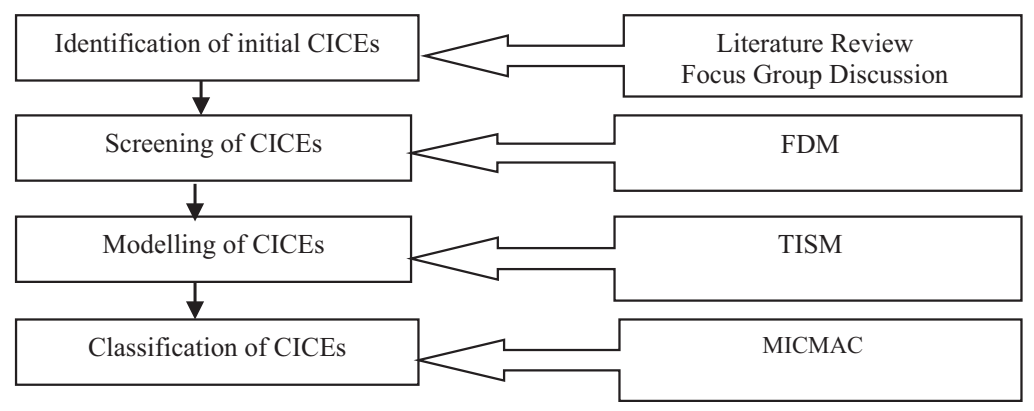

Figure 1.

Linguistic variable

Absolutely unimportant

Unimportant

Slightly unimportant

Neutral

Slightly important

Important

Important
Continuous innovation capability enablers 
2017 and 2018. The experts were expected to provide various inputs related to companies' abilities to survive and grow amid the crisis and industrial challenges in Indonesia.

A total of 26 experts (13 academic experts and industrial experts each) fit the above criteria. The experts' willingness was confirmed through phone calls, and then questionnaires containing initial CICEs were sent via email, in the form of a Google Survey Form. However, only 17 experts filled out and returned valid questionnaires, leading to a survey response rate of $65 \%$. This number (17 experts) met the requirements where the size of the homogeneous experts ranged from 10 to 15 (Manakandan et al., 2017).

3.2.2 Calculation of triangular fuzzy number and defuzzification. This process began by changing all the linguistic terms (one-seven points) to a fuzzy scale. For example, the linguistic term seven was changed to three fuzzy scales: $0.9 ; 1.0 ; 1.0$, with the calculation of the triangular number performed using the following formula:

$$
\begin{gathered}
\mathrm{a}_{\mathrm{j}}=\operatorname{Min}_{i}\left\{\mathrm{a}_{\mathrm{ij}}\right\}, \ldots \ldots \ldots \ldots \\
\mathrm{b}_{\mathrm{j}}=-\sum_{n^{i-1 i}}^{1_{n}} \mathrm{~b}_{\mathrm{ij}}, \ldots \ldots \ldots \ldots \\
\mathrm{c}_{\mathrm{j}}=\operatorname{Max}\left\{\mathrm{c}_{\mathrm{j}}\right\} \ldots \ldots \ldots \ldots \ldots
\end{gathered}
$$

Where $n=$ number of experts and $\mathrm{m}=$ number of factors/elements

Defuzzification was then calculated using the following formula:

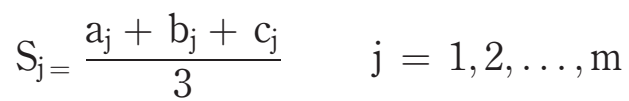

Acceptance or rejection of a factor was carried out using the following principles:

if $S_{j} \geq a, j$ is accepted

if $S_{j}<a$, j is rejected; where $\alpha=0,75$

\subsection{Modelling of continuous innovation capability enablers}

A relationship was developed among the CICEs, using the TISM method, which has been

\begin{tabular}{|c|c|c|c|}
\hline No & Qualification & Academic expert & Industrial experts \\
\hline 1 & Knowledge & $\begin{array}{l}\text { They are experts in industrial } \\
\text { engineering, manufacturing systems, } \\
\text { strategy and management of innovation, } \\
\text { technological innovation and } \\
\text { organizational innovation }\end{array}$ & $\begin{array}{l}\text { The practitioners work in fields } \\
\text { related to production, product } \\
\text { development, business development, } \\
\text { R\&D, technology development }\end{array}$ \\
\hline 2 & Skill & $\begin{array}{l}\text { Possesses at least a } \mathrm{PhD} \text { with a good } \\
\text { track record in research }\end{array}$ & $\begin{array}{l}\text { The practitioners have worked as } \\
\text { middle/upper managers for at least } \\
\text { five years }\end{array}$ \\
\hline
\end{tabular}
widely used in the development of several fields (Dubey et al., 2015; Jena et al., 2017; Rajesh, 2017; Shibin et al., 2017). The TISM method applied in this study consists of the following seven stages (Rajesh, 2017), as shown in Table 3.

Table 2.

Qualifications of academic experts and industry practitioners 


\subsection{Classification of continuous innovation capability enablers}

The classification of CICEs was carried out using MICMAC. This analysis works on the principle of the multiplication properties of the matrices (Diabat and Govindan, 2011). The basis of this classification is "driving power" and "dependence power" which are calculated in the final reachability matrix (FRM) of the previous stage.

Continuous innovation capability enablers

\section{Research result}

The results are presented in the order of research stages, i.e. identification of CICEs in Indonesia's manufacturing industries, modelling of the contextual relationship between the CICEs and the classification of driving power and dependence power of CICEs.

\subsection{Continuous innovation capability enablers}

The identification of CICEs resulted in 21 initial CICEs, which were then grouped into seven dimensions. A total of 18 CICEs were obtained from the literature review and 3 from the industry practitioners' input. The results of CICEs grouping based on seven dimensions and operational definitions are shown in Table 4:

After going through the four stages of FDM's screening with a threshold value of $\alpha \geq$ 0.75 (accepted) and $\alpha<0.75$ (rejected), the results are as shown in Table 5:

The table above shows that 16 of the initial 21 CICEs items are accepted, while five are rejected. The five rejected CICEs are digital capabilities (0.74), skills and education (0.73), organizational agility (0.74), knowledge assets (0.64) and access to external financing (0.72). The 16-accepted CICEs were then entered into modelling process using TISM.

\subsection{Modelling and classification of continuous innovation capability enablers}

The process of modelling and classifying the CICEs is performed out through the following stages:

4.2.1 Selection of experts. In addition to determining the CICEs through the aforementioned screening process, another step in the TISM method is the selection of an expert team. The opinions of the members are input to develop a pattern of contextual relationships between CICEs. The respondents (experts) involved in this stage are a member of the management of manufacturing industry associations, institutions and government agencies. Aside from being manufacturing company practitioners, they also represent the general view of existing industrial problems and conditions. The experts from industry and government agencies are people with an adequate understanding of the condition of the manufacturing sector in Indonesia. They came from five manufacturing sectors prioritized in the Making Indonesia 4.0 Programme, namely, automotive, chemical, electronics, textiles and clothing and the

\begin{tabular}{|c|c|}
\hline Stage 1 & Identify and determine the main elements and expert team \\
\hline Stage 2 & $\begin{array}{l}\text { Develop a SSIM to describe the pattern of contextual relationships between the main } \\
\text { elements. The development was carried out by a team of experts }\end{array}$ \\
\hline Stage 3 & Develop a DRM by transforming the SSIM data into a binary matrix \\
\hline Stage 4 & Develop FRM by checking the transitive relations between elements \\
\hline Stage 5 & Determine the bulkhead level of each element/factor based on the FRM \\
\hline Stage 6 & $\begin{array}{l}\text { Develop a relationship pattern diagram between the elements/factors based on the level of } \\
\text { significance of the relationship and the bulkhead level }\end{array}$ \\
\hline Stage 7 & Validate the total interpretive structural model \\
\hline
\end{tabular}

Table 3. Stage of TISM method 


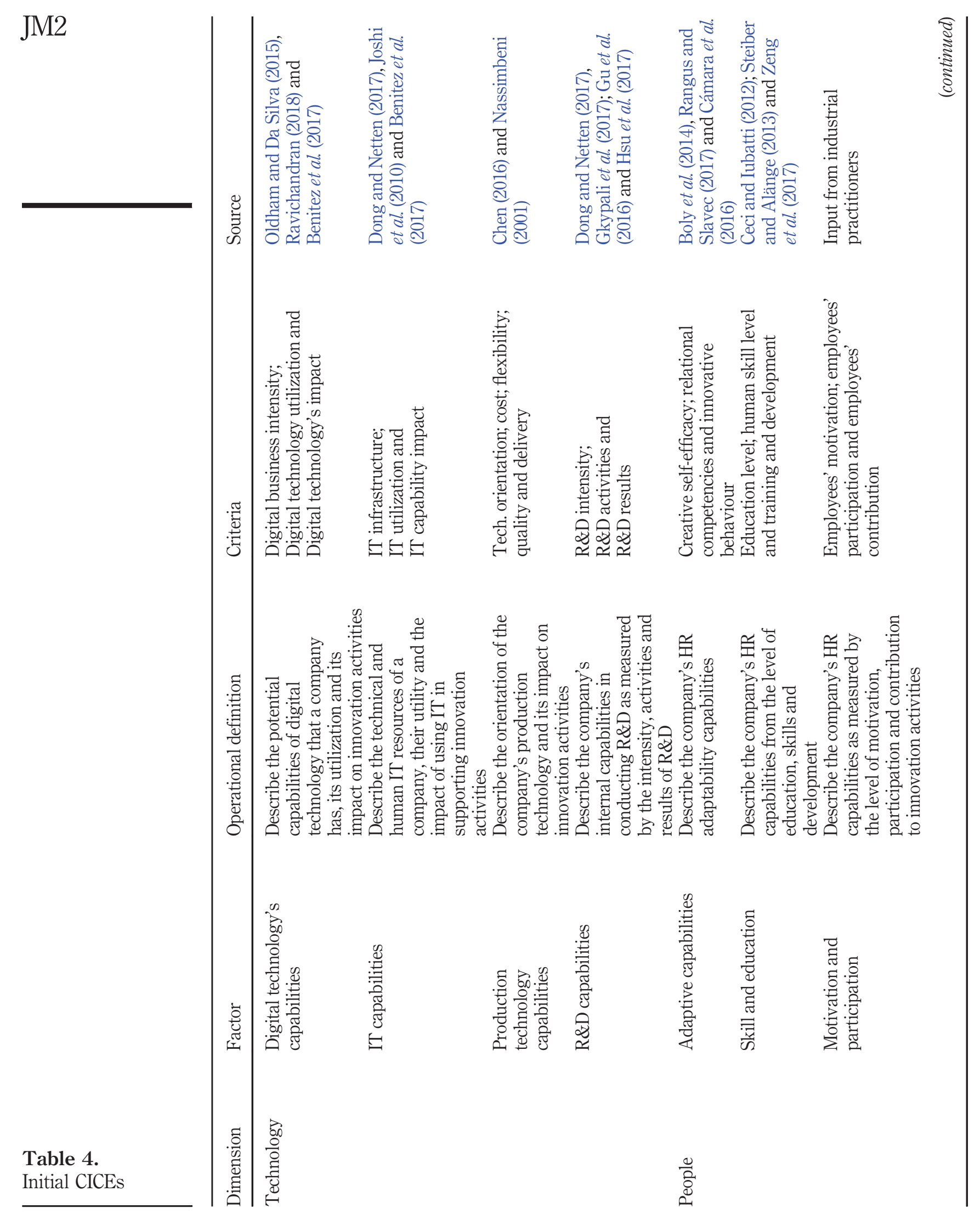




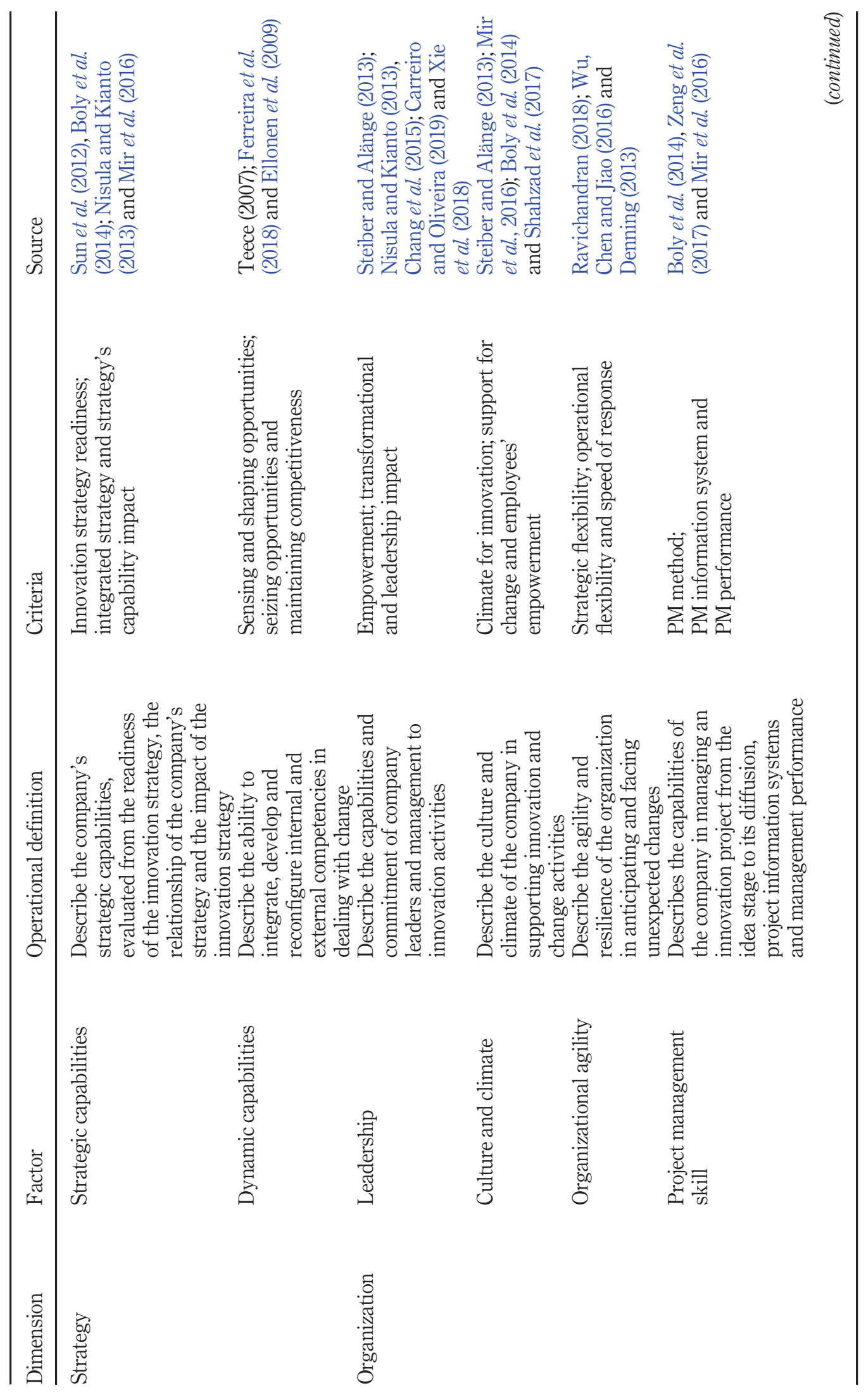

Continuous innovation capability enablers 


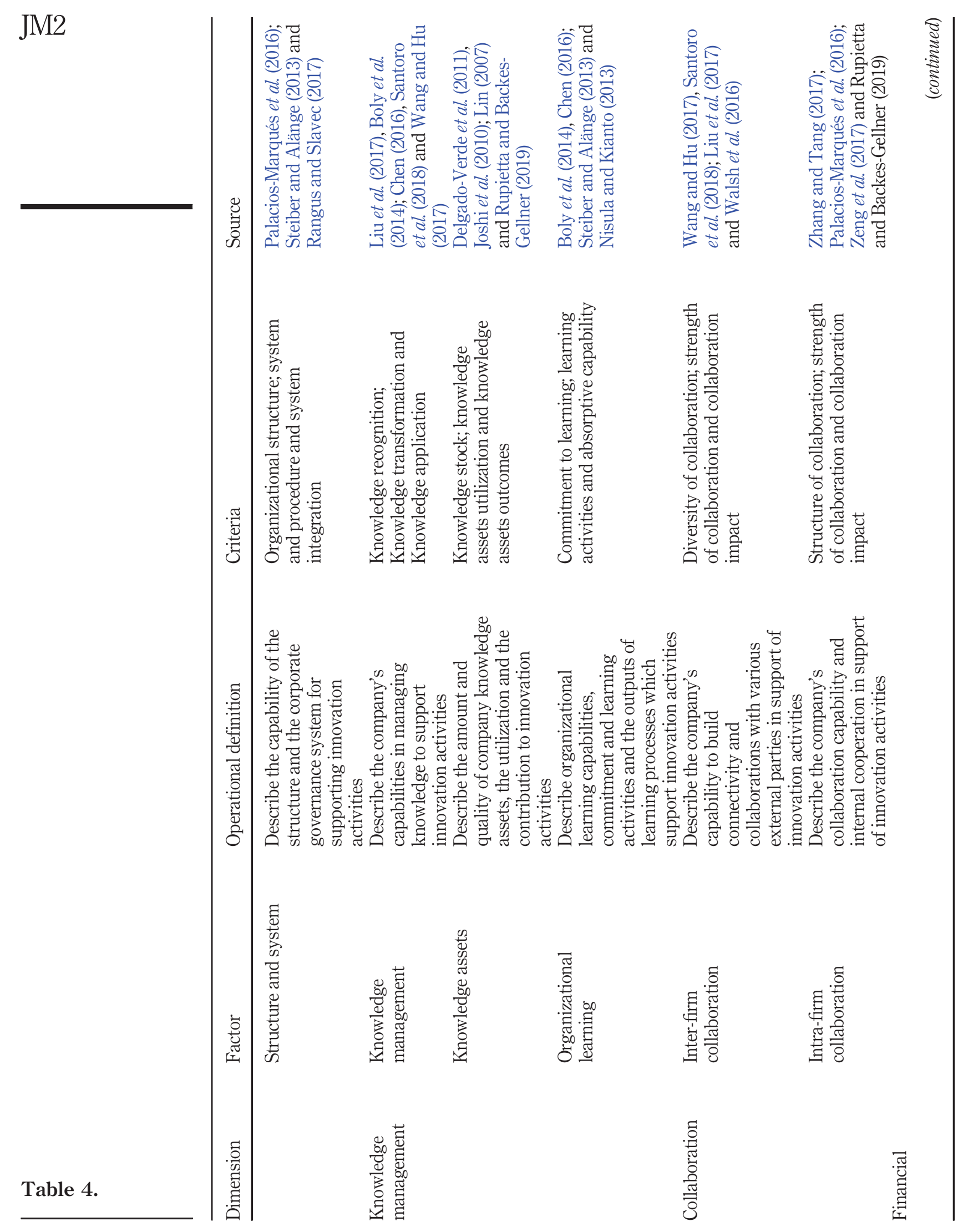




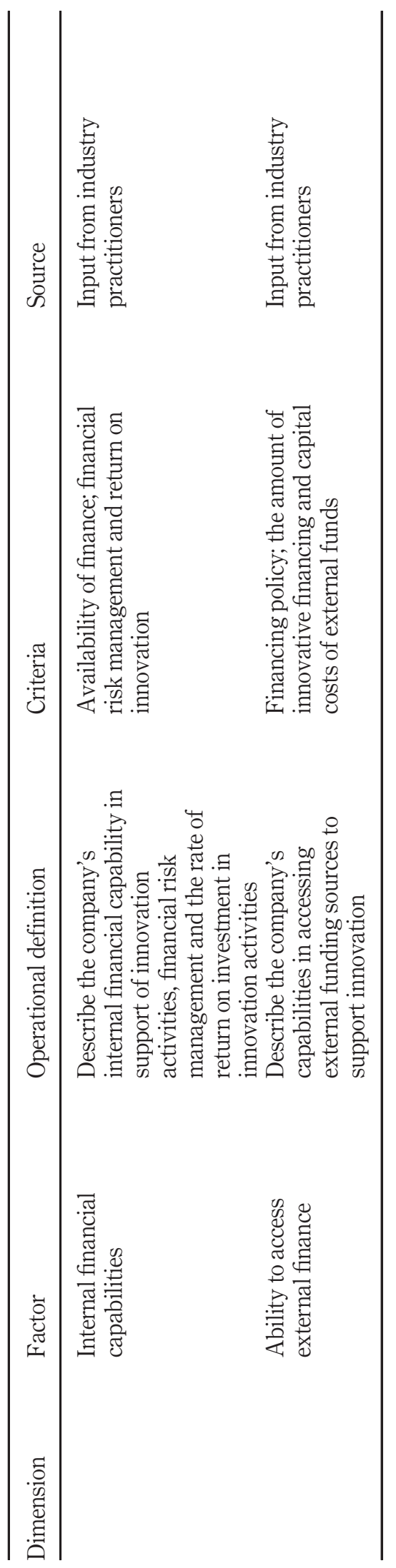

Continuous innovation capability enablers

Table 4. 
food industry. Based on the above criteria, nine expert respondents were involved in this study and their profile is shown in Table 6.

4.2.2 Development of structural self-interaction matrix. Structural self-interaction matrix (SSIM) illustrates the pattern of contextual relationships between CICEs, of which the process of building a connection pattern between them is performed by a team of experts. In this study, the process of experts' opinion collection was conducted in two stages. In the initial stage, a questionnaire interview form was sent by email to all respondents with a preference given to the management of industrial associations. It was filled and submitted to all members of the associations for further discussion at the industry associations' management meetings. In the second stage, in-depth interviews were conducted with nine expert respondents separately. During the interview process, the experts were asked to provide an assessment of the level of connectedness between the CICEs. The relationship level values are presented in the form of linguistic variables as follows:

The convergence process of the nine experts' opinions is done for each pattern of the relationship from factor $i$ to $j$ using the principle of a majority decision (Kamble et al., 2018), and presented in Table 7. For example, the values on the relationship of $\mathrm{F} 1$ to $\mathrm{F} 15$ by nine experts are $\mathrm{V} ; \mathrm{V} ; \mathrm{V} ; \mathrm{X} ; \mathrm{O} ; \mathrm{V} ; \mathrm{X} ; \mathrm{V}$. Five experts gave a pattern of relation $\mathrm{V}$, two experts gave $\mathrm{X}$ and only one expert gave $\mathrm{O}$. It means that the pattern of relations of F1 to F15 is V or factor 1; which influences the 15th factor. Assuming the two relationship patterns possess the same amount, then discussions with several experts are needed to choose one of the two. The SSIM convergence of all the experts is also displayed in Table 8.

4.2.3 Development of direct reachability matrix. The direct reachability matrix (DRM) development is performed by transforming the SSIM data into a binary matrix (zero or one). The value in the reachability matrix depends on the type of relationship in SSIM (Valmohammadi and Dashti, 2016) and is summarized as follows:

\begin{tabular}{|c|c|c|c|c|c|c|}
\hline Dimension & Factor & Min & Max & $\begin{array}{l}\text { Score } \\
\text { Average }\end{array}$ & De-fuzzy & Hasil \\
\hline \multirow[t]{4}{*}{ Technology } & Digital capabilities- & 0.3 & 1 & 0.91 & 0.74 & Rejected \\
\hline & IT capabilities $(\mathrm{F} 1)$ & 0.7 & 1 & 0.96 & 0.89 & Accepted \\
\hline & Production technology capabilities (F2) & 0.5 & 1 & 0.95 & 0.82 & Accepted \\
\hline & Internal R\&D capabilities (F3) & 0.3 & 1 & 0.94 & 0.75 & Accepted \\
\hline \multirow[t]{3}{*}{ People } & Adaptive capabilities (F4) & 0.7 & 1 & 0.98 & 0.89 & Accepted \\
\hline & Skill and education- & 0.3 & 1 & 0.9 & 0.73 & Rejected \\
\hline & Motivation and participation (F5) & 0.7 & 1 & 0.98 & 0.89 & Accepted \\
\hline \multirow[t]{2}{*}{ Strategy } & Integrated strategic capabilities (F6) & 0.5 & 1 & 0.91 & 0.8 & Accepted \\
\hline & Dynamic capabilities (F7) & 0.5 & 1 & 0.95 & 0.82 & Accepted \\
\hline \multirow[t]{5}{*}{ Organization } & Leadership (F8) & 0.5 & 10 & 0.94 & 0.81 & Accepted \\
\hline & Culture and climate (F9) & 0.5 & 1 & 0.92 & 0.81 & Accepted \\
\hline & Organizational agility- & 0.3 & 1 & 0.91 & 0.74 & Rejected \\
\hline & Project management skill (F10) & 0.5 & 1 & 0.94 & 0.81 & Accepted \\
\hline & Structure and system (F11) & 0.5 & 1 & 0.92 & 0.81 & Accepted \\
\hline \multirow[t]{3}{*}{ Knowledge management } & Knowledge management capacity (F12) & 0.5 & 1 & 0.91 & 0.8 & Accepted \\
\hline & Knowledge assets- & 0.1 & 1 & 0.83 & 0.64 & Rejected \\
\hline & Organizational learning (F13) & 0.3 & 1 & 0.96 & 0.75 & Accepted \\
\hline \multirow[t]{2}{*}{ Collaboration } & Inter-firm collaboration (F14) & 0.5 & 1 & 0.93 & 0.81 & Accepted \\
\hline & Intra-firm collaboration (F15) & 0.5 & 1 & 0.94 & 0.81 & Accepted \\
\hline \multirow[t]{2}{*}{ Financial } & Internal financing capabilities (F16) & 0.3 & 1 & 0.94 & 0.75 & Accepted \\
\hline & Access to external financing- & 0.1 & 1 & 0.83 & 0.72 & Rejected \\
\hline
\end{tabular}

Table 5.

CICEs after FDM screening 


\begin{tabular}{lll}
\hline Expert & Pftosition & Industry \\
\hline P1 & President of the Indonesian Automotive Institute & Automotive \\
P2 & Chairperson of the Indonesian Association of Basic Inorganic Chemicals & Chemical \\
P3 & Secretary of the Indonesian Association of Basic Inorganic Chemicals & Chemical \\
P4 & Director for the Electronic and ICT Industry, Ministry of Industry & Electronics \\
P5 & Chairperson of the Indonesian Electronics and Electrical Equipment & Electronics \\
& Industry Association & Textiles and \\
P6 & Chairperson of the Indonesian Textile Association & clothing \\
& Chairperson of the Indonesia-East Java Textile Association & Textiles and \\
P7 & clothing \\
& Chairperson of the development committee of the Indonesian Food and & Food and \\
P8 & Beverage \\
& Chairperson of the Indonesian Food and Beverage Entrepreneurs & Food and \\
P9 & Association - East Java region &
\end{tabular}

Continuous innovation capability enablers

Note: ICT = Information and Communication Technology

Table 6.

List of TISM experts

\begin{tabular}{|c|c|c|}
\hline Verbal rating scale & Relationship & \\
\hline $\begin{array}{l}\text { Sub element } i \text { contributes to sub-element } j \\
\text { Sub element } j \text { contributes to sub-element } i \\
\text { Sub element } i \text { contributes to sub-elements } j \\
\text { Sub element } i \text { does not contribute to sub-elements } j\end{array}$ & $\begin{array}{l}\mathrm{V} \\
\mathrm{A} \\
\mathrm{X} \\
\mathrm{O}\end{array}$ & $\begin{array}{r}\text { Table } 7 . \\
\text { Value of the level of } \\
\text { relationship between } \\
\text { factors }\end{array}$ \\
\hline
\end{tabular}

\begin{tabular}{|c|c|c|c|c|c|c|c|c|c|c|c|c|c|c|c|c|}
\hline Factor & F16 & F15 & F14 & F13 & F12 & F11 & F10 & $\begin{array}{l}J \\
\mathrm{~F}\end{array}$ & F8 & F7 & F6 & F5 & F4 & F3 & $\mathrm{F} 2$ & $\mathrm{~F} 1$ \\
\hline F1 & A & $\mathrm{V}$ & $\mathrm{V}$ & V & V & $\mathrm{V}$ & $\mathrm{V}$ & A & A & V & $\mathrm{V}$ & A & $\mathrm{V}$ & $\mathrm{O}$ & $\mathrm{O}$ & \\
\hline $\mathrm{F} 2$ & X & $\mathrm{O}$ & $\mathrm{O}$ & $\mathrm{O}$ & $\mathrm{O}$ & $\mathrm{O}$ & $\mathrm{O}$ & $\mathrm{O}$ & A & V & $\mathrm{O}$ & $\mathrm{O}$ & $\mathrm{O}$ & X & & \\
\hline F3 & A & A & A & A & A & A & A & A & A & X & A & A & A & & & \\
\hline $\mathrm{F} 4$ & A & X & V & V & A & A & $\mathrm{O}$ & A & A & X & A & A & & & & \\
\hline F5 & A & V & V & V & V & A & $\mathrm{O}$ & A & A & $\mathrm{V}$ & $\mathrm{O}$ & & & & & \\
\hline F6 & X & X & X & A & X & $\mathrm{V}$ & $\mathrm{O}$ & A & A & $\mathrm{V}$ & & & & & & \\
\hline F7 & $\mathrm{O}$ & A & A & A & A & A & $\mathrm{O}$ & A & A & & & & & & & \\
\hline F8 & $\mathrm{V}$ & V & V & V & V & $\mathrm{V}$ & $\mathrm{V}$ & $\mathrm{X}$ & & & & & & & & \\
\hline F9 & $\mathrm{O}$ & V & V & V & V & V & $\mathrm{O}$ & & & & & & & & & \\
\hline F10 & $\mathrm{O}$ & A & $\mathrm{O}$ & A & X & A & & & & & & & & & & \\
\hline F11 & V & V & V & V & V & & & & & & & & & & & \\
\hline $\mathrm{F} 12$ & $\mathrm{O}$ & A & A & X & & & & & & & & & & & & \\
\hline $\mathrm{F} 13$ & $\mathrm{O}$ & A & A & & & & & & & & & & & & & \\
\hline F14 & $\mathrm{O}$ & X & & & & & & & & & & & & & & \\
\hline F15 & $\mathrm{O}$ & & & & & & & & & & & & & & & \\
\hline D16 & & & & & & & & & & & & & & & & \\
\hline
\end{tabular}

Table 8.

Self-structural interaction matrix

- If the relationship between the variables in one row and the other variables in the column is "V", then in the initial reachability matrix, the row entry becomes "one" while the column entry between these two variables becomes "zero"; (V if eij = one and eji $=$ zero). 
- If the relationship between variables in one row and other variables in the column is "A", then in the initial reachability matrix, the row entry becomes "zero" while the column entry between these two variables becomes "one"; (A if eij = zero and eji = one).

- If the relationship between variables in one row and other variables in the column is " $\mathrm{X}$ ", then in the initial reachability matrix, the row entry becomes "one" while the column entry between these two variables becomes "one"; $(\mathrm{X}$ if eij $=$ one and eji $=$ one).

- If the relationship between variables in one row and other variables in the column is "O", then in the initial reachability matrix, the row entry becomes "zero" while the column entry between these two variables becomes "zero"; (O if eij = zero and eji = zero).

The DRM results are shown in Table 9:

4.2.4 Final reachability matrix. Development of the FRM is conducted by checking the transitive relations (transitivity checks) between the CICEs. Transitivity checking aims to form a closed matrix. It is carried out on cells with a value of zero, irrespective of whether the value meets the transitivity rules or not.

Transitivity in contextual relationships is a basic assumption made in TISM. According to this concept, if the variable $\mathrm{X}$ is related to $\mathrm{Y}$ and $\mathrm{Y}$ is related to $\mathrm{Z}$, then $\mathrm{X}$ must be related to Z (Venkatesh et al., 2015; Yadav and Barve, 2016).

The transitivity check rules used in this study are as follows (Sushil, 2017):

- If $\mathrm{i}-\mathrm{j} / \mathrm{i}=\mathrm{j}$ and $\mathrm{j}-\mathrm{k} / \mathrm{j}=\mathrm{k}$ then $\mathrm{i}-\mathrm{k}$

- If $\mathrm{j}-\mathrm{i} / \mathrm{i}=\mathrm{j}$ and $\mathrm{k}-\mathrm{j} / \mathrm{j}=\mathrm{k}$ then $\mathrm{k}-\mathrm{i}$

- If $\mathrm{i}=\mathrm{j}$ and $\mathrm{j}=\mathrm{k}$ then $\mathrm{i}=\mathrm{k}$

For example, cell $(1,2)=0$ because $(1,4)=1$ and $(4,2)=1$ then $(1,2)$ needs to be $=1$ The results of FRM development can be seen in Figure 2 and Tables 10-14

Table 9.

Direct reachability

\begin{tabular}{cccccccccccccccccc}
\multicolumn{1}{c}{ Factor } & F1 & F2 & F3 & F4 & F5 & F6 & F7 & F8 & F9 & F10 & F11 & F12 & F13 & F14 & F15 & F16 \\
\hline $\boldsymbol{i}$ & F1 & 1 & 0 & 0 & 1 & 0 & 1 & 1 & 0 & 0 & 1 & 1 & 1 & 1 & 1 & 1 & 0 \\
F2 & 0 & 1 & 1 & 0 & 0 & 0 & 1 & 0 & 0 & 0 & 0 & 0 & 0 & 0 & 0 & 1 \\
F3 & 0 & 1 & 1 & 0 & 0 & 0 & 1 & 0 & 0 & 0 & 0 & 0 & 0 & 0 & 0 & 0 \\
F4 & 0 & 0 & 1 & 1 & 0 & 0 & 1 & 0 & 0 & 0 & 0 & 0 & 1 & 1 & 1 & 1 \\
F5 & 1 & 0 & 1 & 1 & 1 & 0 & 1 & 0 & 0 & 0 & 0 & 1 & 1 & 1 & 1 & 1 \\
F6 & 0 & 0 & 1 & 1 & 0 & 1 & 1 & 0 & 0 & 0 & 1 & 1 & 0 & 1 & 1 & 1 \\
F7 & 0 & 0 & 1 & 1 & 0 & 0 & 1 & 0 & 0 & 0 & 0 & 0 & 0 & 0 & 0 & 0 \\
F8 & 1 & 1 & 1 & 1 & 1 & 1 & 1 & 1 & 1 & 1 & 1 & 1 & 1 & 1 & 1 & 1 \\
F9 & 1 & 0 & 1 & 1 & 1 & 1 & 1 & 1 & 1 & 0 & 1 & 1 & 1 & 1 & 1 & 0 \\
F10 & 0 & 0 & 1 & 0 & 0 & 0 & 0 & 0 & 0 & 1 & 0 & 1 & 0 & 0 & 0 & 0 \\
F11 & 0 & 0 & 1 & 1 & 1 & 0 & 1 & 0 & 0 & 1 & 1 & 1 & 1 & 1 & 1 & 1 \\
F12 & 0 & 0 & 1 & 1 & 0 & 1 & 1 & 0 & 0 & 1 & 0 & 1 & 1 & 1 & 1 & 0 \\
F13 & 0 & 0 & 1 & 0 & 0 & 1 & 1 & 0 & 0 & 1 & 0 & 1 & 1 & 1 & 1 & 0 \\
F14 & 0 & 0 & 1 & 0 & 0 & 1 & 1 & 0 & 0 & 0 & 0 & 0 & 0 & 1 & 1 & 0 \\
F15 & 0 & 0 & 1 & 1 & 0 & 1 & 1 & 0 & 0 & 1 & 0 & 0 & 0 & 1 & 1 & 0 \\
F16 & 1 & 1 & 1 & 0 & 0 & 1 & 0 & 0 & 0 & 0 & 0 & 0 & 0 & 0 & 0 & 1 \\
\hline
\end{tabular}




\begin{tabular}{|c|c|c|c|c|c|c|c|c|c|c|c|c|c|c|c|c|c|c|c|}
\hline \multirow{2}{*}{\multicolumn{2}{|c|}{ Factor }} & \multicolumn{16}{|c|}{$\mathrm{J}$} & \multirow[t]{2}{*}{$\begin{array}{l}\text { Driving } \\
\text { Power }\end{array}$} & \multirow[t]{2}{*}{ Rank } \\
\hline & & F1 & F2 & F3 & F4 & F5 & F6 & F7 & F8 & F9 & F10 & F11 & $\mathrm{F} 12$ & F13 & F14 & F15 & F16 & & \\
\hline & F1 & 1 & 0 & 1 & 1 & 1 & 1 & 1 & 0 & 0 & 1 & 1 & 1 & 1 & 1 & 1 & 1 & 13 & III \\
\hline & F2 & 0 & 1 & 1 & 1 & 0 & 0 & 1 & 0 & 0 & 0 & 0 & 0 & 0 & 0 & 0 & 1 & 5 & VIII \\
\hline & F3 & 0 & 1 & 1 & 1 & 0 & 0 & 1 & 0 & 0 & 0 & 0 & 0 & 1 & 1 & 1 & 0 & 7 & VII \\
\hline & F4 & 0 & 1 & 1 & 1 & 0 & 1 & 1 & 0 & 0 & 1 & 1 & 1 & 1 & 1 & 1 & 0 & 11 & $\mathrm{~V}$ \\
\hline \multirow{12}{*}{$\mathrm{i}$} & F5 & 1 & 1 & 1 & 1 & 1 & 1 & 1 & 0 & 0 & 1 & 1 & 1 & 1 & 1 & 1 & 0 & 13 & III \\
\hline & F6 & 1 & 1 & 1 & 1 & 1 & 1 & 1 & 0 & 0 & 1 & 1 & 1 & 1 & 1 & 1 & 1 & 14 & II \\
\hline & F7 & 0 & 1 & 1 & 1 & 0 & 1 & 1 & 0 & 0 & 1 & 1 & 1 & 1 & 1 & 1 & 0 & 11 & V \\
\hline & F8 & 1 & 1 & 1 & 1 & 1 & 1 & 1 & 1 & 1 & 1 & 1 & 1 & 1 & 1 & 1 & 1 & 16 & I \\
\hline & F9 & 1 & 1 & 1 & 1 & 1 & 1 & 1 & 1 & 1 & 1 & 1 & 1 & 1 & 1 & 1 & 1 & 16 & I \\
\hline & F10 & 0 & 1 & 1 & 1 & 0 & 1 & 1 & 0 & 0 & 1 & 1 & 1 & 1 & 1 & 1 & 0 & 11 & VI \\
\hline & F11 & 1 & 1 & 1 & 1 & 1 & 1 & 1 & 0 & 0 & 1 & 1 & 1 & 1 & 1 & 1 & 1 & 14 & II \\
\hline & F12 & 0 & 1 & 1 & 1 & 0 & 1 & 1 & 0 & 0 & 1 & 1 & 1 & 1 & 1 & 1 & 1 & 12 & IV \\
\hline & F13 & 0 & 1 & 1 & 1 & 1 & 1 & 1 & 0 & 0 & 1 & 1 & 1 & 1 & 1 & 1 & 1 & 13 & III \\
\hline & F14 & 0 & 1 & 1 & 1 & 1 & 1 & 1 & 0 & 0 & 1 & 1 & 1 & 1 & 1 & 1 & 1 & 13 & III \\
\hline & F15 & 0 & 1 & 1 & 1 & 1 & 1 & 1 & 0 & 0 & 1 & 1 & 1 & 1 & 1 & 1 & 1 & 13 & III \\
\hline & F16 & 1 & 1 & 1 & 1 & 1 & 1 & 1 & 0 & 0 & 1 & 1 & 1 & 1 & 1 & 1 & 1 & 14 & II \\
\hline & $\begin{array}{l}\text { Dependence } \\
\text { power }\end{array}$ & 7 & 15 & 16 & 16 & 10 & 14 & 16 & 2 & 2 & 14 & 14 & 14 & 15 & 15 & 15 & 10 & & \\
\hline
\end{tabular}

: Transitivity cells
Continuous innovation capability enablers

Figure 2.

Final reachability matrix

\begin{tabular}{lllll}
\hline Factor & \multicolumn{1}{c}{ Reachability set } & \multicolumn{1}{c}{ Antecedent set } & \multicolumn{1}{c}{ Intersection set } & Level \\
\hline F1 & $1,3,4,5,6,7,10,11,12,13,14,15,16$ & $1,5,6,8,9,11,16$ & $1,5,6,11,16$ & \\
F2 & $2,3,4,7,16$ & $2,3,4,5,6,7,8,9,10,11,12,13,14,15,16$ & $2,3,4,7,16$ & 1 \\
F3 & $2,3,4,7,13,14,15$ & $1,2,3,4,5,6,7,8,9,10,11,12,13,14,15,16$ & $2,3,4,7,13,14,15$ & 1 \\
F4 & $2,3,4,6,7,10,11,12,13,14,15$ & $1,2,3,4,5,6,7,8,9,10,11,12,13,14,15,16$ & $2,3,4,6,7,10,11,12,13,14,15$ & 1 \\
F5 & $1,2,3,4,5,6,7,10,11,12,13,14,15$ & $1,5,6,8,9,11,13,14,15,16$ & $1,5,6,11,13,14,15$ & \\
F6 & $1,2,3,4,5,6,7,10,11,12,13,14,15,16$ & $1,4,5,6,7,8,9,10,11,12,13,14,15,16$ & $1,4,5,6,7,10,11,12,13,14,15,16$ & 1 \\
F7 & $2,3,4,6,7,10,11,12,13,14,15$ & $1,2,3,4,5,6,7,8,9,10,11,12,13,14,15,16$ & $2,3,4,6,7,10,11,12,13,14,15$ & 1 \\
F8 & $1,2,3,4,5,6,7,8,9,10,11,12,13,14,15,16$ & 8,9 & 8,9 & \\
F9 & $1,2,3,4,5,6,7,8,9,10,11,12,13,14,15$ & 8,9 & 8,9 & \\
F10 & $2,3,4,6,7,10,11,12,13,14,15$ & $1,4,5,6,7,8,9,10,11,12,13,14,15$ & $4,6,7,10,11,12,13,14,15$ & \\
F11 & $1,2,3,4,5,6,7,10,11,12,13,14,15,16$ & $1,4,5,6,7,9,10,11,12,13,14,15,16$ & $1,4,5,6,7,10,11,12,13,14,15,16$ & \\
F12 & $2,3,4,6,7,10,11,12,13,14,15,16$ & $1,4,5,6,7,8,9,10,11,12,13,14,15,16$ & $4,6,7,10,11,12,13,14,15,16$ & \\
F13 & $2,3,4,5,6,7,10,11,12,13,14,15,16$ & $1,3,4,5,6,7,8,9,10,11,12,13,14,15,16$ & $3,4,5,6,7,10,11,12,13,14,15,16$ & \\
F14 & $2,3,4,5,6,7,10,11,12,13,14,15,16$ & $1,3,4,5,6,7,8,9,10,11,12,13,14,15,16$ & $3,4,5,6,7,10,11,12,13,14,15,16$ & \\
F15 & $2,3,4,5,6,7,10,11,12,13,14,15,16$ & $1,3,4,5,6,7,8,9,10,11,12,13,14,15,16$ & $3,4,5,6,7,10,11,12,13,14,15,16$ & \\
F16 & $1,2,3,4,5,6,7,10,11,12,13,14,15,16$ & $1,5,6,8,9,11,12,13,14,15,16$ & $1,5,6,11,12,13,4,15,16$ & \\
\end{tabular}

Table 10.

Level partition of factors (iteration 1 )

\begin{tabular}{|c|c|c|c|c|c|}
\hline Factor & Reachability set & Antecedent set & Intersection set & Level & \\
\hline $\mathrm{F} 1$ & 1,5,6,10,11,12,13,14,15,16 & $1,5,6,8,9,11,16$ & $1,5,6,11,16$ & & \\
\hline F5 & $1,5,6,10,11,12,13,14,15$ & $1,5,6,8,9,11,13,14,15,16$ & $1,5,6,11,13,14,15$ & & \\
\hline F6 & $1,5,6,10,11,12,13,14,15,16$ & $1,5,6,8,9,10,11,12,13,14,15,16$ & $1,5,6,10,11,12,13,14,15,16$ & 2 & \\
\hline F8 & $1,5,6,8,9,10,11,12,13,14,15,16$ & 8,9 & 8,9 & & \\
\hline F9 & $1,5,6,8,9,10,11,12,13,14,15$ & 8,9 & 8,9 & & \\
\hline $\mathrm{F} 10$ & $6,10,12,13,14,15$ & $1,5,6,8,9,10,11,12,13,14,15$ & $6,10,12,13,14,15$ & 2 & \\
\hline F11 & $1,5,6,10,11,12,13,14,15,16$ & $1,5,6,9,11,12,13,14,15,16$ & $1,5,6,11,12,13,14,15,16$ & & \\
\hline $\mathrm{F} 12$ & $6,10,11,12,13,14,15,16$ & $1,5,6,8,9,10,11,12,13,14,15,16$ & $6,10,11,12,13,14,15$ & 2 & \\
\hline $\mathrm{F} 13$ & $5,6,10,11,12,13,14,15,16$ & $1,5,6,8,9,10,11,12,13,14,15,16$ & $5,6,10,11,12,13,14,15,16$ & 2 & \\
\hline $\mathrm{F} 14$ & $5,6,10,11,12,13,14,15,16$ & $1,5,6,8,9,10,11,12,13,14,15,16$ & $5,6,10,11,12,13,14,15,16$ & 2 & \\
\hline $\mathrm{F} 15$ & $5,6,10,11,12,13,14,15,16$ & $1,5,6,8,9,10,11,12,13,14,15,16$ & $5,6,10,11,12,13,14,15,16$ & 2 & Level partition of \\
\hline $\mathrm{F} 16$ & $1,5,6,10,11,12,13,14,15,16$ & $1,5,6,8,9,11,12,13,14,15,16$ & $1,5,6,11,12,13,14,15,16$ & & factors (iteration 2) \\
\hline
\end{tabular}


4.2.5 Determining level partition of factors. Next, a level partition was conducted for the FRM which had fulfilled the transitivity rules. The process of determining the level factor bulkhead of each CICEs is tabulated with the following format filling:

4.2.6 Development of relationship pattern diagram between continuous innovation capability enablers. The level partition of factors describes the initial structural model of TISM from the CICEs, followed by the validation process by the experts. The level of connection between the two factors was also evaluated using a Likert scale of one-five. Level one (1) means that the experts strongly disagree about the relationship between elements, while five (5) shows the opposite. When the average score obtained is three $(60 \%)$, the relationship between elements is accepted and when it is $<60 \%$, the connection is eliminated (Rajesh, 2017). Validated TISM models for the relationship pattern diagram between the CICEs are shown in Figure 3.

4.2.7 Development of matrix of cross-impact multiplications applied to classification. MICMAC is used to classify the system variables studied. The basis of this classification is the driving power and dependence power, which are calculated in the FRM at the TISM stage. Based on the driving power and dependence power, the enablers in this study are classified and described into four groups, as follows:

(1) Autonomous factor (Quadrant I: weak driver - weak dependent variables): these enablers do not have much influence or dependency or only having a micro-effect on the system. In this study, there are no CICEs included in Quadrant I, which shows that the identification and screening process of the CICEs conducted by the first panel of experts using the FDM method was accurate. This was validated by the second panel of experts using the TISM method.

\begin{tabular}{lllllr} 
& Factor & Reachability set & Antecedent set & Intersection set & Level \\
\cline { 2 - 6 } & F1 & $1,5,11,16$ & $1,5,8,9,11,16$ & $1,5,11,16$ & 3 \\
& F5 & $1,5,11$ & $1,5,8,9,11,16$ & $1,5,11$ & 3 \\
Table 12. & F8 & $1,5,8,9,11,16$ & 8,9 & 8,9 & \\
Level partition of & F9 & $1,5,8,9,11,16$ & 8,9 & 8,9 & 3 \\
factors (iteration 3) & F1 & $1,5,11,16$ & $1,5,9,11,16$ & $1,5,11,16$ & 3 \\
\hline
\end{tabular}

Table 13.

Level partition of

\begin{tabular}{lcccc}
\hline Factor & Reachability set & Antecedent set & Intersection set & Level \\
\hline F8 & 8,9 & 8,9 & 8,9 & 4 \\
F9 & 8,9 & 8,9 & 8,9 & 4 \\
\hline
\end{tabular}

\begin{tabular}{lllr}
\hline Factors $-\mathrm{i}$ & Relationship & \multicolumn{1}{c}{ Factor $-\mathrm{j}$} & Mean \\
\hline IT capabilities & $\mathbf{V}$ & Adaptive capabilities & 4.33 \\
IT capabilities & $\mathbf{A}$ & Leadership & 4.33 \\
IT capabilities & $\mathbf{X}$ & Structure and system & 4.22 \\
IT capabilities & $\mathbf{V}$ & Inter-firm collaboration & 4.22 \\
Internal R\&D & $\mathbf{A}$ & Leadership & 4.22 \\
\hline
\end{tabular}




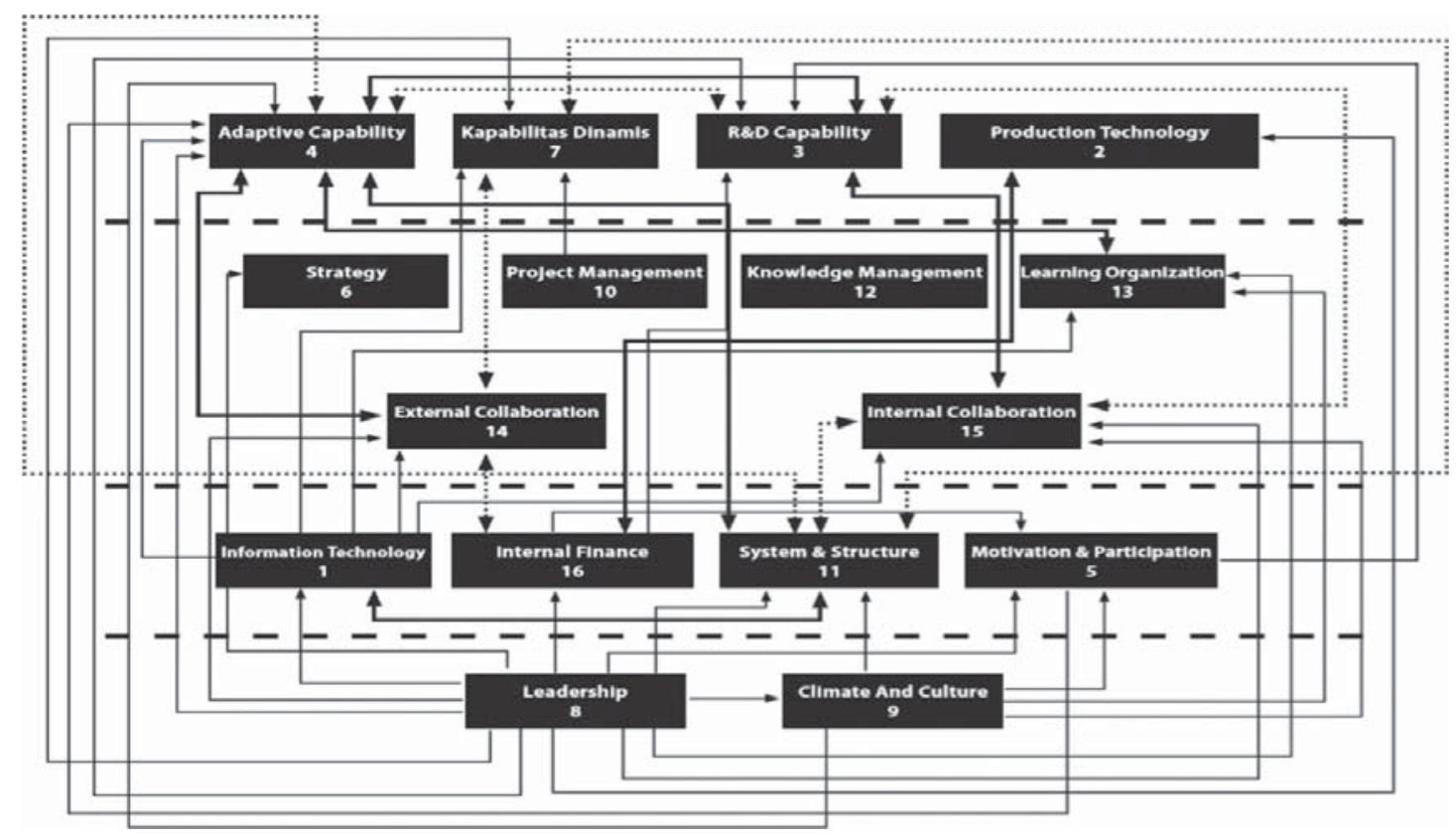

Continuous innovation capability enablers

Figure 3. Validated TISM model

(2) Factor Dependent (Quadrant II: weak driver - strongly dependent variables): these enablers have little effect with high dependency. The MICMAC analysis shows that production technology $(\mathrm{F} 2)$ and internal $\mathrm{R} \& \mathrm{D}$ capabilities $(\mathrm{F} 3)$ are dependent enablers. The CICEs are categorized as dependent factors because they are driven by independent factors. Figure 4 shows that internal R\&D (F3) is strongly influenced by leadership (F8), climate and culture (F9), as well as information technology ( $\mathrm{F} 1)$; while production technology (F2) is largely determined by the leadership factor (F8). In addition, R\&D capability is also influenced by some CICEs' environment categories such as human resources (HR) motivation and participation (F5), project management (F10) and internal finance (F16). Some of the CICEs relationships affecting R\&D are the adaptive capabilities of $\mathrm{HR}(\mathrm{F} 4)$ and the internal collaboration (F15), while production influences internal finance (F16).

(3) Factor Linkage (Quadrant III: strong driver - strongly dependent variables): these enablers have a high degree of influence as well as dependence and every action or change affects their superiors. There are a significant number of CICEs included in Quadrant III of this study, i.e.: adaptive capability (F4), HR motivation and participation (F5), strategy capability (F6), dynamic capability (F7), project management capability (F10), system and structure (F11), knowledge management (F12), learning organization (F13), external collaboration (F14), internal collaboration (F15) and internal finance capability (F16). The CICEs contained in Quadrant III need to be carefully studied and deactivated because their interactions tend to affect the system.

(4) Factor Independent (Quadrant IV: strong driver - weak dependent variables): independent enablers are the most important due to their high-level driving power and low-level dependence power. The CICEs in this quadrant have a strong influence on the system and largely determine a company's continuous innovation capability. Three types of CICEs in this study belong to Quadrant IV, namely, leadership (F8), climate and culture (F9) and information technology (F1). 


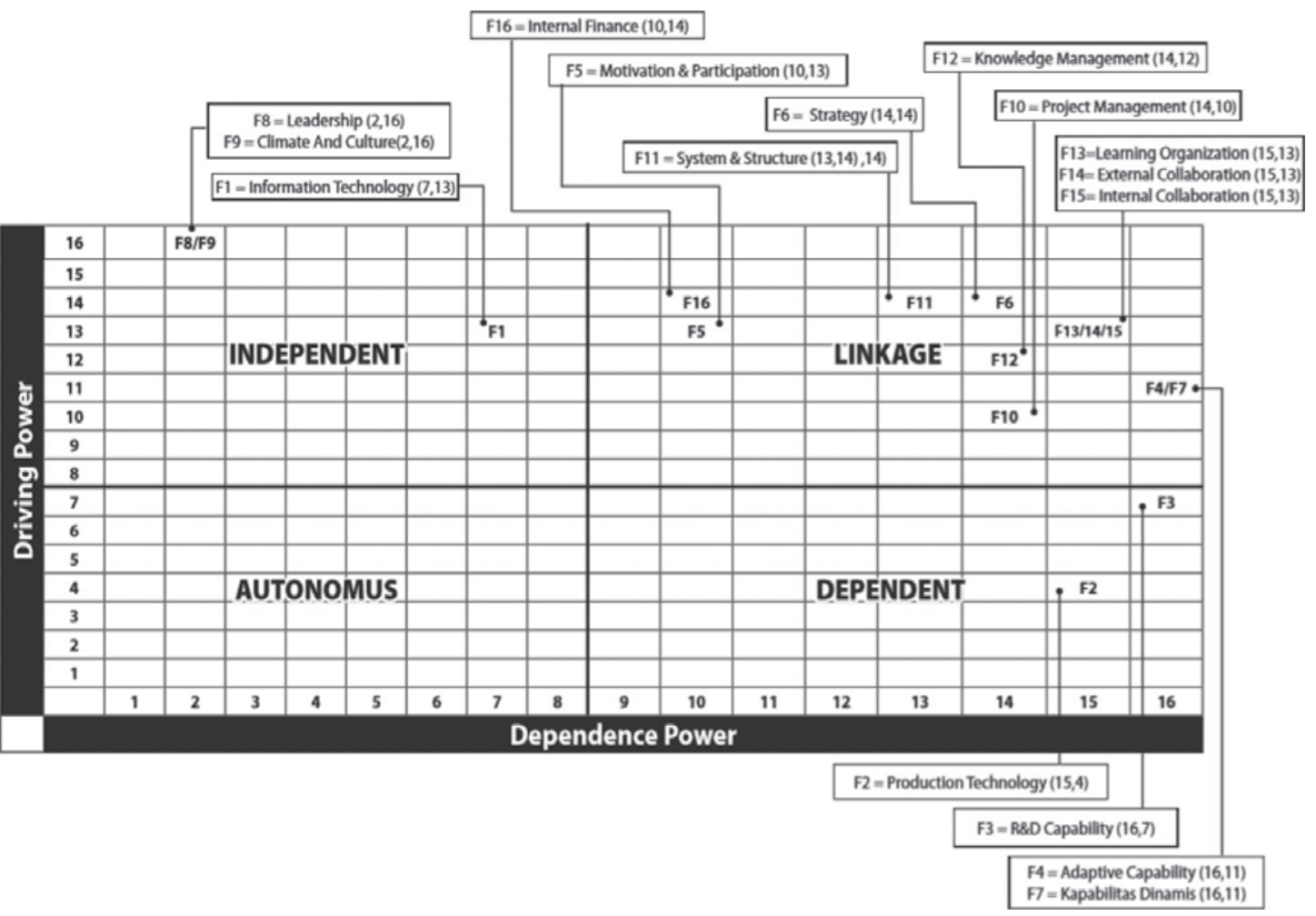

Figure 4.

Diagram of driving power and dependence power of CICEs

Leadership (F8), as well as climate and culture (F9), are factors with the greatest driving power and lowest dependence power (16.2) followed by information technology (F1) (13.7). The results of this study indicate that efforts to continuously develop innovation capabilities of Indonesia's manufacturing industry are strongly influenced by leadership capability (F8), climate and culture (F9) and information technology's capability (F1).

\section{Findings and discussions}

The objective of this paper is to identify and screen CICEs in Indonesia's manufacturing sectors, to develop a relationship among these enablers and to determine their driving power and dependence power in the sector.

Initial CICEs' identification process was conducted using a literature review and focus group discussion with industry practitioners. The identification process resulted in 21 initial CICEs; which were then grouped into seven dimensions. In total, 18 CICEs were obtained from the literature study and three CICEs were from the industry practitioners' input. After passing through the four stages of fuzzy Delphi screening (Hsu et al., 2010) with a threshold value of $\alpha \geq 0.75$ (accepted) and $\alpha<0.75$ (rejected), a total of 16 factors were accepted, while five were rejected. The rejected factors were digital technology, skills and education, organizational agility, knowledge assets and access to external finance. The following points discuss rejected CICEs in this study:

- Interview results show that most of the experts agreed that knowledge assets capability, contained in humans and technology, are not meaningful to the company - with the lowest fuzzy value of 0.64 . Companies are more concerned with the ability to use assets for innovation efforts, which led to a de-fuzzy value of 0.74 for digital 
platform technology (close to the threshold value). These assessment results confirm the opinion of several experts that manufacturing industries in Indonesia are not ready to move towards digital factories. A lengthy preparation is, thus, needed before the manufacturing processes can use knowledge assets effectively, especially in terms of the data's completeness, the availability of hardware and software for simulation, as well as the ability of the workers (Sunardi and Saputra, 2016). Research on digital transformation in developing countries conducted by Gonzalez et al. (2017) concluded that generally, industries have very little confidence or trust in digital transactions. The results of initial discussions with the manufacturing industry practitioners indicate that companies need an IT capability more than a digital technology capability.

- On the other hand, skills and education levels have a de-fuzzy value of 0.73 , prompting most of the experts to provide a neutral judgement or consider them as something rather important. Today, the level of education and skills is used administratively as a benchmark and in general, is focused on the number of diplomas and certificates. However, in practice, motivation and the ability to adapt are more important than the level of education and skills. In the current era, companies embracing Industry 4.0 need people who are willing to keep improving on themselves by continuously learning from various internal and external sources using technological advancements (Briganti and Samson, 2019).

- The organizational agility factor is rejected with a de-fuzzy value of 0.74. Several experts claim that agility is more determined by the human aspect rather than by the organization. It has been observed by Sindhwani and Malhotra (2017), who stated that manufacturing agility is determined by human aspects such as flexible workforce, manpower utilization and top management support.

- There are two CICEs from industry practitioners' input that are related to financial dimensions. Although it is rarely mentioned as a determinant, several studies have shown that finance influences innovation capability. Abdu and Jibir (2018) mentioned that the financial capabilities of a company affect its innovation activities. Studies conducted on nine African companies also shows that corporate financial limitations have a significant and negative effect on innovation (Lorenz, 2014). A study investigating the determinants of innovation in companies in Indonesia found that finance determines the development of innovation in small and medium-sized companies, while its development in large-scale companies is determined by other factors such as their institutional quality (Mahendra et al., 2015). Guariglia and Liu (2014) show that based on the results of investigations into 120,000 companies in China from 2000 to 2017, Chinese private and foreign investment companies' innovation activities are determined by the availability of internal corporate cash flows, while the influence of financial aspects on stateowned companies tends to be lower.

The rest of CICEs were then entered modelling process using TISM. There are 5 contextual relationships between CICEs having a strong relationship, i.e.:

Leadership capability strongly affects (A) IT capability with a relationship mean of 4.33. Investment in IT infrastructure to stay up to date, stable, reliable, also to provide improvement in IT people skill and IT utilization in a company is determined by strategic decisions from upper management. In this study, discussion with manufacturing industry practitioners concluded that decision-related to IT investment is a very strategic decision 
and create a wide effect, including on innovation activities. Leadership capability also strongly influences R\&D capability, with a relationship mean of 4.22 . The intensity of R\&D activities as measured from sufficient investment and the number of employees involved is determined by company leaders and their commitment. A leader capable of building an effective team of R\&D and its communication mechanisms will significantly improve R\&D capability (Paulsen et al., 2009). Concrete support from company leaders also drives R\&D employees to be firm in initiating ideas for product innovation.

On the other hand, IT capability strongly affects and contributes to (V) human resources adaptive capability with a relationship mean of 4.33 . Good IT capability will help in disseminating information upward/downward, so the company and its employees can adapt swiftly to changes (Chae et al., 2018). IT capability also has reciprocal interaction (X) with an organizational system and structure (relationship mean of 4.22). High IT capability will support the system and organizational structure integration and vice versa. The implementation of e-business technology, for example, is proven to affect a company's planning and operational performance, system integration with suppliers and consumers, the company's flexibility level and production systems - to support innovation activities (Devaraj et al., 2007). Good organizational structure and system will contribute to IT utilization for innovation activities in the form of improvement on the quality and quantity of information sharing in the whole company (Prajogo and Olhager, 2012). IT capability also has a strong effect (V) on inter-firm collaboration capability (relationship mean of 4.22). With a good support level of IT capability, a company could collaborate effectively with external parties to support innovation activities. A company's IT capability will influence information sharing and information quality needed in supply chain collaboration, particularly with suppliers and consumers (Afshan et al., 2018). The availability of reliable IT infrastructure will better facilitate communications to build external connectivity and collaboration - for example, to get product information from consumers, when exchanging knowledge with research and academic institutions and in information sharing with associations and government bodies (Olesen and Myers, 1999).

Further analysis on CICEs with TISM and MICMAC reveals that leadership (F8) and climate and culture (F9), are factors with the highest driving power and the lowest dependence powers (16.2); followed by information technology (F1) (13.7). Analysis of the contextual relationship between CICEs shows that leadership is the most dominant factor. The results of this study are in line with previous studies, they show that leadership greatly influences the performance of corporate innovation and is a key determinant for an organization to successfully adopt an innovation (Ding et al., 2018; Xie et al., 2018; Carreiro and Oliveira, 2019). Meanwhile, Xie et al. (2011) stated that the leadership style considerably affects the innovation atmosphere in a company and can facilitate trust and individuals' identification. Chang et al. (2015) also mentioned that leadership is the key to facilitating innovation activities and tends to affect the success of companies in emerging countries. This opinion applies to manufacturing companies in Indonesia, where leaders play a critical role in various activities and in the innovation process because they are more powerful and autocratic.

Culture and climate in a company gives several strong effects on other CICEs. Previous studies also show that climate and culture determine the innovation performance of a company (Shahzad et al., 2017). A strong organizational culture tends to significantly stimulate the creativity and innovation behaviour of employees by creating formal rules and regulations with an open climate for employees to develop ideas and creativity (Naranjo-Valencia et al., 2016). Multiple effects of IT capability on other CICEs were also observed. A number of past studies on innovation capabilities in manufacturing industries in several countries highlight 
that IT capabilities are CICEs with a positive effect on continuous innovation capabilities (Dong and Netten, 2017; Joshi et al.2010; Benitez et al., 2017; Chen et al., 2015).

\section{Conclusion, implications, limitations and scope for future work 6.1 Conclusion}

This paper identified 21 initial CICEs, grouped into seven dimensions; of which 18 CICEs were obtained from the literature study and three CICEs from industry practitioners' input. After passing through the four stages of fuzzy Delphi screening with a threshold value of $\alpha \geq 0.75$ (accepted) and $\alpha<0.75$ (rejected), a total of 16 factors were accepted, while five were rejected. The rejected CICEs were digital technology, skills and education, organizational agility, knowledge assets and access to external finance.

Analysis of the contextual relationship between 16 selected CICEs resulted in 5 strong contextual relationships, as follows: leadership capability on IT, leadership capability on R\&D capability, IT capability on human resources adaptive capability, IT capability on structure and system capability and IT capability on inter-firm collaboration capability.

TISM results and MICMAC analysis show that leadership and climate and culture are enablers with the highest driving power and the lowest dependence powers, followed by information technology. The results of this study indicate that efforts to continuously develop innovation capabilities in Indonesia's manufacturing industries are strongly influenced by leadership capability, climate and culture and information technology capability. It has been observed that long-term innovation capability is asserted when there is strong industry leadership, encouraging climate and culture of innovation and sufficient support of prevailing information technology.

\subsection{Implication}

The practical implication from this study is to give insights and assurance to manufacturing industry management and leaders that critical factors in developing sustainable innovation capabilities are leadership, culture and climate and IT capability. With this information, priority on the company's improvement should start from improving leadership capability, building a conducive working climate and culture, as developing reliable IT capability. Without considering these 3 capabilities, a high amount of investment and effort to enhance innovation capability will not be performed as expected. This study will also contribute to advance the holistic knowledge of innovation through a comprehensive understanding of prominent CICEs, their relationship patterns, as well as driving power and dependence power in Indonesia's manufacturing industry.

\subsection{Limitations and scope for future work}

This study has several limitations as follows. The identification process of initial CICEs using the literature review approach, which covers similar industries in other countries, may not necessarily be in accordance with the conditions found in the manufacturing industries in Indonesia; although they have been verified by manufacturing industry practitioners through a focus group discussion. For future research, a content analysis approach should be performed in addition to literature review; by studying various documents, notes, books and reports from various government and non-government institutions related to the manufacturing industries in Indonesia.

The process to converge expert opinions in developing contextual relationships between CICEs in this study was conducted using the majority decision approach; and this approach has limitations because experts do not have the opportunity to present their arguments when providing an assessment of the level of connectedness between CICEs. Further 
research should use a focus group discussion approach for this convergence process. If convergence is not reached during the focus group discussion, only then the majority decision approach can take place.

\section{References}

Ab Rahman, M.N., Doroodian, M., Kamarulzaman, Y. and Muhamad, N. (2015), "Designing and validating a model for measuring", Sustainability of Sustainability, Vol. 7 No. 1, pp. 537-562, doi: 10.3390/su7010537.

Abdu, M. and Jibir, A. (2018), "Determinants of firms innovation in Nigeria”, Kasetsart Journal of Social Sciences, Vol. 39 No. 3, pp. 448-456, doi: 10.1016/j.kjss.2017.07.006.

Afshan, N., Chatterjee, S. and Chhetri, P. (2018), "Impact of information technology and relational aspect on supply chain collaboration leading to financial performance: a study in indian context”, Benchmarking: An International Journal, Vol. 25 No. 7, pp. 2496-2511, doi: 10.1108/BIJ09-2016-0142.

Afuah, A. (2002), "Mapping technological capabilities into product markets and competitive advantage: the case of cholesterol drugs", Strategic Management Journal, Vol. 23 No. 2, pp. 171-179, doi: 10.1002/smj.221.

Ali, Z., Sun, H. and Ali, M. (2017), "The impact of managerial and adaptive capabilities to stimulate organizational innovation in SMEs: a complementary PLS-SEM approach", Sustainability (Sustainability), Vol. 9 No. 12, doi: 10.3390/su9122157.

Allarakhia, M. and Walsh, S. (2011), "Managing knowledge assets under conditions of radical change: the case of the pharmaceutical industry”, Technovation, Vol. 31 No. 2-3, pp. 105-117, doi: 10.1016/ j.technovation.2010.11.001.

Allen, M.R., Adomdza, G.K. and Meyer, M.H. (2015), "Managing for innovation: managerial control and employee level outcomes", Journal of Business Research, Vol. 68 No. 2, pp. 371-379, doi: 10.1016/j. jbusres.2014.06.021.

Aramburu, N. and Sáenz, J. (2011), "Structural capital, innovation capability, and size effect: an empirical study", Journal of Management and Organization, Vol. 17 No. 3, pp. 307-325, doi: 10.5172/jmo.2011.17.3.307.

Banerjee, C. (2014), The Human Factor: The Fundamental Driver of Innovation, The Global Innovation Index.

Ben Moussa, N. and El Arbi, R. (2020), "The impact of human resources information systems on individual innovation capability in Tunisian companies: the moderating role of affective commitment", European Research on Management and Business Economics, Vol. 26 No. 1, pp. 18-25, doi: 10.1016/j.iedeen.2019.12.001.

Benitez, J., Castillo, A., Llorens, J. and Braojos, J. (2017), "IT-enabled knowledge ambidexterity and innovation performance in small U.S. firms: the moderator role of social media capability", Information and Management, Vol. 55 No. 1, pp. 131-143, doi: 10.1016/j.im.2017.09.004.

Bessant, J., Alexander, A., Tsekouras, G., Rush, H. and Lamming, R. (2012), "Developing innovation capability through learning networks", Journal of Economic Geography, Vol. 12 No. 5, pp. 1087-1112, doi: 10.1093/jeg/lbs026.

Bittner, J.V. and Heidemeier, H. (2013), "Competitive mindsets, creativity, and the role of regulatory focus”, Thinking Skills and Creativity, Vol. 9, pp. 59-68, doi: 10.1016/j.tsc.2013.03.003.

Björkdahl, J. and Börjesson, S. (2012), “Assessing firm capabilities for innovation”, International Journal of Knowledge Management Studies, Vol. 5 Nos 1/2, pp. 171-184, doi: 10.1504/IJKMS.2012.051970.

Boer, H. and Gertsen, F. (2003), "From continuous improvement to continuous innovation: a (retro) (per) spective harry boer and frank gertsen*", International Journal of Technology Management, Vol. 26 No. 8, pp. 805-827. 
Boly, V., Morel, L., Assielou, N.G. and Camargo, M. (2014), "Evaluating innovative processes in French firms: methodological proposition for firm innovation capacity evaluation”, Research Policy, Vol. 43 No. 3, pp. 608-622, doi: 10.1016/j.respol.2013.09.005.

Briganti, S.E. and Samson, A. (2019), "Innovation talent as a predictor of business growth", International Journal of Innovation Science, Vol. 11 No. 2, pp. 261-277, doi: 10.1108/IJIS-10-2018-0102.

Continuous innovation capability enablers

Cai, Z., Liu, H., Huang, Q. and Liang, L. (2017), "Developing organizational agility in product innovation: the roles of IT capability, KM capability, and innovative climate", $R \& D$ Management, Vol. 49 No. 4, pp. 421-438, doi: 10.1111/radm.12305.

Cámara, J., Lopes, A., Garlan, D. and Schmerl, B. (2016), "Adaptation impact and environment models for architecture-based self-adaptive systems", Science of Computer Programming, Vol. 127, pp. 50-75, doi: 10.1016/j.scico.2015.12.006.

Carreiro, H. and Oliveira, T. (2019), "Impact of transformational leadership on the diffusion of innovation in firms: application to mobile cloud computing", Computers in Industry, Vol. 107, pp. 104-113, doi: 10.1016/j.compind.2019.02.006.

Ceci, F. and Iubatti, D. (2012), "Personal relationships and innovation diffusion in SME networks: a content analysis approach”, Research Policy, Vol. 41 No. 3, pp. 565-579, doi: 10.1016/j. respol.2011.10.003.

Chae, H.C., Koh, C.E. and Park, K.O. (2018), "Information technology capability and firm performance: role of industry", Information and Management, Vol. 55 No. 5, pp. 525-546, doi: 10.1016/j. im.2017.10.001.

Chang, J., Bai, X. and Li, J.J. (2015), "The influence of leadership on product and process innovations in China: the contingent role of knowledge acquisition capability", Industrial Marketing Management, Vol. 50, pp. 18-29, doi: 10.1016/j.indmarman.2015.04.014.

Chapman, R. and Hyland, P. (2004), "Complexity and learning behaviors in product innovation", Technovation, Vol. 24 No. 7, pp. 553-561, doi: 10.1016/S0166-4972(02)00121-9.

Chapman, R.L. and Magnusson, M.G. (2006), "Continuous innovation, performance and knowledge management: an introduction", Knowledge and Process Management, Vol. 13 No. 3, pp. 129-131.10.1002/kpm.

Chen, S. (2016), "The influencing factors of enterprise sustainable innovation: an empirical study", doi: $10.3390 /$ su8050425.

Chen, Y., Wang, Y., Nevo, S., Benitez-Amado, J. and Kou, G. (2015), "IT capabilities and product innovation performance: the roles of corporate entrepreneurship and competitive intensity", Information and Management, Vol. 52 No. 6, pp. 643-657, doi: 10.1016/j.im.2015.05.003.

Cho, J. and Lee, J. (2013), "Development of a new technology product evaluation model for assessing commercialization opportunities using delphi method and fuzzy AHP approach", Expert Systems with Applications, Vol. 40 No. 13, pp. 5314-5330, doi: 10.1016/j.eswa.2013.03.038.

Chutivongse, N. and Gerdsri, N. (2018), "Creating an innovative organization: analytical approach to develop a strategic roadmap guiding organizational development", Journal of Modelling in Management, Vol. 15 No. 1, pp. 50-88, doi: 10.1108/JM2-05-2018-0067.

Delgado-Verde, M., Martín-de Castro, G. and Navas-López, J.E. (2011), "Organizational knowledge assets and innovation capability: evidence from spanish manufacturing firms", Journal of Intellectual Capital, Vol. 12 No. 1, pp. 5-19, doi: 10.1108/14691931111097890.

Denning, S. (2013), "Why agile can be a game changer for managing continuous innovation in many industries”, Strategy and Leadership, Vol. 41 No. 2, pp. 5-11, doi: 10.1108/10878571311318187.

Devaraj, S., Krajewski, L. and Wei, J.C. (2007), "Impact of eBusiness technologies on operational performance: the role of production information integration in the supply chain", Journal of Operations Management, Vol. 25 No. 6, pp. 1199-1216, doi: 10.1016/j.jom.2007.01.002.

Dewangan, V. and Godse, M. (2014), "Towards a holistic enterprise innovation performance measurement system”, Technovation, Vol. 34 No. 9, pp. 536-545, doi: 10.1016/j.technovation.2014.04.002. 
Diabat, A. and Govindan, K. (2011), "An analysis of the drivers affecting the implementation of green supply chain management”, Resources, Conservation and Recycling, Vol. 55 No. 6, pp. 659-667, doi: 10.1016/j.resconrec.2010.12.002.

Ding, W., Choi, E. and Aoyama, A. (2018), "Relational study of wise (phronetic) leadership, knowledge management capability, and innovation performance", Asia Pacific Management Review, Vol. 24 No. 4, doi: 10.1016/j.apmrv.2018.10.005.

Dong, Y., Bartol, K.M., Zang, Z.X. and Li, C. (2016), "Enhancing employee creativity via individual skill development and team knowledge sharing: influences of dual-focused transformational leadership", Journal of Organizational Behavior, doi: 10.1002/job.

Dong, J.Q. and Netten, J. (2017), "Information technology and external search in the open innovation age: new findings from Germany", Technological Forecasting and Social Change, Vol. 120, pp. 223-231, doi: 10.1016/j.techfore.2016.12.021.

Dubey, R., Gunasekaran, A., Wamba, S.F. and Bag, S. (2015), "Building theory of green supply chain management using total interpretive structural modeling (TISM)", IFAC-PapersOnLine, Vol. 48 No. 3, pp. 1688-1694, doi: 10.1016/j.ifacol.2015.06.329.

Efthyvoulou, G. and Vahter, P. (2013), "Financial constraints, innovation performance and sectoral disaggregation georgios efthyvoulou priit vahter updated: December 2013 financial constraints, innovation performance. 2012030".

Eisenhardt, K.M. and Martin, J.A. (2000), "Dynamic capabilities: what are they?", Strategic Management Journal, Vol. 21 Nos 10/11, pp. 1105-1121, doi: 10.1002/1097-0266(200010/11)21:10/ $11<1105:: A I D-S M J 133>3.0 . C O ; 2-\mathrm{E}$.

Ellonen, H.K., Wikström, P. and Jantunen, A. (2009), "Linking dynamic-capability portfolios and innovation outcomes”, Technovation, Vol. 29 No. 11, pp. 753-762, doi: 10.1016/j.technovation.2009.04.005.

Fernandez, S. and Pitts, D.W. (2011), "Understanding employee motivation to innovate: evidence from front line employees in United States federal agencies", Australian Journal of Public Administration, Vol. 70 No. 2, pp. 202-222, doi: 10.1111/j.1467-8500.2011.00726.x.

Ferreira, J., Coelho, A. and Moutinho, L. (2018), "Dynamic capabilities, creativity and innovation capability and their impact on competitive advantage and firm performance: the moderating role of entrepreneurial orientation", Technovation, Vols 92/93, November, 102061 doi: 10.1016/j. technovation.2018.11.004.

Ferreira, J.J.M., Fernandes, C.I. and Ferreira, F.A.F. (2019), "To be or not to be digital, that is the question: firm innovation and performance”, Journal of Business Research, Vol. 101, pp. 583-590, doi: 10.1016/j.jbusres.2018.11.013.

Foumani, M. and Smith-Miles, K. (2019), "The impact of various carbon reduction policies on green flowshop scheduling", Applied Energy, Vol. 249, pp. 300-315, doi: 10.1016/j.apenergy.2019.04.155.

Foumani, M., Razeghi, A. and Smith-Miles, K. (2020), "Stochastic optimization of two-machine flow shop robotic cells with controllable inspection times: from theory toward practice", Robotics and Computer-Integrated Manufacturing, Vol. 61, p. 101822, doi: 10.1016/j.rcim.2019.101822.

Gachanja, I.M., Nga'nga', S.I. and Kiganane, L.M. (2020), "Influence of organization learning on innovation output in manufacturing firms in Kenya", International Journal of Innovation Studies, Vol. 4 No. 1, pp. 16-26, doi: 10.1016/j.ijis.2020.02.001.

Gkypali, A., Filiou, D. and Tsekouras, K. (2017), "R\&D collaborations: is diversity enhancing innovation performance?”, Technological Forecasting and Social Change, Vol. 118, pp. 143-152, doi: 10.1016/j.techfore.2017.02.015.

Gonzalez, A., Casahuga, G., Schlautmann, A. and Romero, M. (2017), "Digital transformation in developing countries: Promotion and adoption should be the main actions".

Gonzalez-Brambila, C.N., Veloso, F.M. and Krackhardt, D. (2013), "The impact of network embeddedness on research output", Research Policy, Vol. 42 No. 9, pp. 1555-1567, doi: 10.1016/j. respol.2013.07.008. 
Gu, Q., Jiang, W. and Wang, G.G. (2016), "Effects of external and internal sources on innovation performance in Chinese high-tech SMEs: a resource-based perspective", Journal of Engineering and Technology Management - Management, Vol. 40, pp. 76-86, doi: 10.1016/j. jengtecman.2016.04.003.

Guan, J. and Liu, N. (2016), "Exploitative and exploratory innovations in knowledge network and collaboration network: a patent analysis in the technological field of nano-energy", Research Policy, Vol. 45 No. 1, pp. 97-112, doi: 10.1016/j.respol.2015.08.002.

Guariglia, A. and Liu, P. (2014), "To what extent do financing constraints affect Chinese firms' innovation activities?”, International Review of Financial Analysis, Vol. 36, pp. 223-240, doi: 10.1016/j.irfa.2014.01.005.

Guertler, M.R. and Sick, N. (2020), "Exploring the enabling effects of project management for SMEs in adopting open innovation - a framework for partner search and selection in open innovation projects", International Journal of Project Management, doi: 10.1016/j.ijproman.2020.06.007.

Hernandez, Y. and Cormican, K. (2016), "Towards the effective management of social innovation projects: insights from project management”, Procedia Computer Science, Vol. 100, pp. 237-243, doi: 10.1016/j.procs.2016.09.148.

Hsu, C.H., Chang, A.Y. and Luo, W. (2017), "Identifying key performance factors for sustainability development of SMEs - integrating QFD and fuzzy MADM methods", Journal of Cleaner Production, Vol. 161, pp. 629-645, doi: 10.1016/j.jclepro.2017.05.063.

Hsu, Y.L., Lee, C.H. and Kreng, V.B. (2010), "The application of fuzzy delphi method and fuzzy AHP in lubricant regenerative technology selection", Expert Systems with Applications, Vol. 37 No. 1, pp. 419-425, doi: 10.1016/j.eswa.2009.05.068.

Hyland, P. and Boer, H. (2006), “A continuous innovation framework: some thoughts for consideration”, in Corso, M., Martini, A. and Pellegrini, L. (Eds), Proceedings of the 7th International CINet conference 2006: CI and sustainability - Designing the road ahead.

Iddris, F. (2016), "Determination of residual dalapon in sugarcane by gas chromatograph equipped with electron capture detector (GC-ECD)", Interdisciplinary Journal of Information, Knowledge, and Management, Vol. 11, pp. 235-260, doi: 10.38212/2224-6614.2633.

Javahernia, A. and Sunmola, F. (2017), "A simulation approach to innovation deployment readiness assessment in manufacturing", Production and Manufacturing Research, Vol. 5 No. 1, pp. 1-9, doi: 10.1080/21693277.2017.1322542.

Jena, J., Sidharth, S., Thakur, L.S., Kumar Pathak, D. and Pandey, V.C. (2017), “Total interpretive structural modeling (TISM): approach and application", Journal of Advances in Management Research, Vol. 14 No. 2, pp. 162-181, doi: 10.1108/JAMR-10-2016-0087.

Joshi, K.D., Chi, L., Datta, A. and Han, S. (2010), "Changing the competitive landscape: continuous innovation through IT-enabled knowledge capabilities", Information Systems Research, Vol. 21 No. 3, pp. 472-495, doi: 10.1287/isre.1100.0298.

Ju, X., Ferreira, F.A.F. and Wang, M. (2019), "Innovation, agile project management and firm performance in a public sector-dominated economy: empirical evidence from high-tech small and medium-sized enterprises in China”, Socio-Economic Planning Sciences, September, 100779, doi: 10.1016/j.seps.2019.100779.

Kamble, S.S., Gunasekaran, A. and Sharma, R. (2018), "Analysis of the driving and dependence power of barriers to adopt industry 4.0 in Indian manufacturing industry", Computers in Industry, Vol. 101, pp. 107-119, doi: 10.1016/j.compind.2018.06.004.

Kavanagh, D. and Naughton, E. (2009), "Innovation and project management - exploring the links", $P M$ World Today, Vol. 11 No. 4, pp. 1-7.

Kianto, A., Sáenz, J. and Aramburu, N. (2017), "Knowledge-based human resource management practices, intellectual capital and innovation”, Journal of Business Research, Vol. 81, pp. 11-20, doi: 10.1016/j.jbusres.2017.07.018. 
Kocoglu, I., Imamoglu, S.Z., Ince, H. and Keskin, H. (2012), "Learning, R\&D and manufacturing capabilities as determinants of technological learning: enhancing innovation and firm performance”, Procedia - Social and Behavioral Sciences, Vol. 58, pp. 842-852, doi: 10.1016/j. sbspro.2012.09.1062.

Kou, M., Yang, Y. and Chen, K. (2020), “The impact of external R\&D financing on innovation process from a supply-demand perspective", Economic Modelling, Vol. 92, doi: 10.1016/j. econmod.2020.01.016.

Lawson, B. and Samson, D. (2001), "Developing innovation capability in organisations: a dynamic capabilities approach", International Journal of Innovation Management, Vol. 5 No. 3, pp. 377-400, doi: 10.1142/s1363919601000427.

Lianto, B., Dachyar, M. and Soemardi, T.P. (2018), "Continuous innovation: a literature review and future perspective", International Journal on Advanced Science, Engineering and Information Technology, Vol. 8 No. 3, p. 771, doi: 10.18517/ijaseit.8.3.4359.

Lin, H.F. (2007), "Knowledge sharing and firm innovation capability: an empirical study", International Journal of Manpower, Vol. 28 Nos 3/4, pp. 315-332, doi: 10.1108/01437720710755272.

Liu, X., Huang, Q., Dou, J. and Zhao, X. (2017), "The impact of informal social interaction on innovation capability in the context of buyer-supplier dyads", Journal of Business Research, Vol. 78, pp. 314-322, doi: 10.1016/j.jbusres.2016.12.027.

Lokuge, S., Sedera, D., Grover, V. and Dongming, X. (2019), "Organizational readiness for digital innovation: development and empirical calibration of a construct", Information and Management, Vol. 56 No. 3, pp. 445-461, doi: 10.1016/j.im.2018.09.001.

Lorenz, E. (2014), "Do credit constrained firms in Africa innovate less? A study based on nine African nations", SSRN Electronic Journal, doi: 10.2139/ssrn.2602247.

Lu, Y. and Ramamurthy, K.R. (2011), "The link between IT capability and organizational agility introduction”, MIS Quarterly, Vol. 35 No. 4, pp. 931-954.

Mahendra, E., Zuhdi, U. and Muyanto, R. (2015), "Determinants of firm innovation in Indonesia: the role of institutions and access to finance", Economics and Finance in Indonesia, Vol. 61 No. 3, p. 149, doi: 10.7454/efi.v61i3.512.

Manakandan, S.K., Ismai, R., Jamil, M.R.M. and Ragunath, P. (2017), "Pesticide applicators questionnaire content validation: a fuzzy delphi method", The Medical Journal of Malaysia, Vol. 72 No. 4, pp. 228-235.

Maurer, I., Bartsch, V. and Ebers, M. (2011), "The value of intra-organizational social capital: how it fosters knowledge transfer, innovation performance, and growth", Organization Studies, Vol. 32 No. 2, pp. 157-185, doi: 10.1177/0170840610394301.

Michailova, S. and Zhan, W. (2015), "Dynamic capabilities and innovation in MNC subsidiaries", Journal of World Business, Vol. 50 No. 3, pp. 576-583, doi: 10.1016/j.jwb.2014.10.001.

Mir, M., Casadesús, M. and Petnji, L.H. (2016), "The impact of standardized innovation management systems on innovation capability and business performance: an empirical study", Journal of Engineering and Technology Management - Management, Vol. 41, pp. 26-44, doi: 10.1016/j. jengtecman.2016.06.002.

Mir-Babayev, R. (2015), "Impact of education on innovation performance: evidence from Azerbaijan construction industry", IOSR Journal of Business and ManagementVer. II, Vol. 17 No. 12, pp. 2319-7668, doi: 10.9790/487X-171227580.

Naranjo-Valencia, J.C., Jiménez-Jiménez, D. and Sanz-Valle, R. (2016), "Studying the links between organizational culture, innovation, and performance in spanish companies", Revista Latinoamericana de Psicología, Vol. 48 No. 1, pp. 30-41, doi: 10.1016/j.rlp.2015.09.009.

Nassimbeni, G. (2001), "Technology, innovation capacity, and the export attitude of small manufacturing firms: a logit/tobit model”, Research Policy, Vol. 30 No. 2, pp. 245-262, doi: 10.1016/S0048-7333(99)00114-6. 
Nisula, A.M. and Kianto, A. (2013), "Evaluating and developing innovation capabilities with a structured method", Interdisciplinary Journal of Information, Knowledge, and Management, Vol. 8, pp. 59-82, doi: 10.28945/1902.

Nylund, P.A., Arimany-Serrat, N., Ferras-Hernandez, X., Viardot, E., Boateng, H. and Brem, A. (2019), "Internal and external financing of innovation: sectoral differences in a longitudinal study of European firms", European Journal of Innovation Management, Vol. 23 No. 2, pp. 200-213, doi: 10.1108/EJIM-09-2018-0207.

Oldham, G.R. and Da Silva, N. (2015), "The impact of digital technology on the generation and implementation of creative ideas in the workplace", Computers in Human Behavior, Vol. 42, pp. 5-11, doi: 10.1016/j.chb.2013.10.041.

Olesen, K. and Myers, M.D. (1999), "Trying to improve communication and collaboration with information technology: an action research project which failed", Information Technology and People, Vol. 12 No. 4, pp. 317-332, doi: 10.1108/09593849910301621.

Palacios-Marqués, D., Popa, S. and Mari, P.A.M. (2016), "The effect of online social networks and competency-based management on innovation capability", Journal of Knowledge Management, Vol. 20 No. 3, pp. 499-511, doi: 10.1108/JKM-05-2015-0175.

Palin, K. and Kaartemo, V. (2016), "Employee motivation to participate in workplace innovation via inhouse crowdsourcing", European Journal of Workplace Innovation, Vol. 2 No. 2, pp. 19-40, doi: 10.46364/ejwi.v2i2.387.

Paulsen, N., Maldonado, D., Callan, V.J. and Ayoko, O. (2009), "Charismatic leadership, change and innovation in an R\&D organization", Journal of Organizational Change Management, Vol. 22 No. 5, pp. 511-523, doi: 10.1108/09534810910983479.

Pérez-Luño, A., Cabello Medina, C., Carmona Lavado, A. and Cuevas Rodríguez, G. (2011), "How social capital and knowledge affect innovation", Journal of Business Research, Vol. 64 No. 12, pp. 1369-1376, doi: 10.1016/j.jbusres.2011.01.014.

Prajogo, D.I. (2016), "The strategic fit between innovation strategies and business environment in delivering business performance", International Journal of Production Economics, Vol. 171, pp. 241-249, doi: 10.1016/j.ijpe.2015.07.037.

Prajogo, D. and Olhager, J. (2012), "Supply chain integration and performance: the effects of long-term relationships, information technology and sharing, and logistics integration", International Journal of Production Economics, Vol. 135 No. 1, pp. 514-522, doi: 10.1016/j.ijpe.2011.09.001.

Rajesh, R. (2017), "Technological capabilities and supply chain resilience of firms: a relational analysis using total interpretive structural modeling (TISM)", Technological Forecasting and Social Change, Vol. 118, pp. 161-169, doi: 10.1016/j.techfore.2017.02.017.

Rangus, K. and Slavec, A. (2017), "The interplay of decentralization, employee involvement and absorptive capacity on firms' innovation and business performance", Technological Forecasting and Social Change, Vol. 120, pp. 195-203, doi: 10.1016/j.techfore.2016.12.017.

Rasiah, R., Shahrivar, R.B. and Yap, X.S. (2016), "Institutional support, innovation capabilities and exports: evidence from the semiconductor industry in Taiwan", Technological Forecasting and Social Change, Vol. 109, pp. 69-75, doi: 10.1016/j.techfore.2016.05.015.

Ravichandran, T. (2018), "Exploring the relationships between IT competence, innovation capacity and organizational agility", The Journal of Strategic Information Systems, Vol. 27 No. 1, pp. 22-42, doi: 10.1016/j.jsis.2017.07.002.

Reichert, F.M., Beltrame, R.S., Corso, K.B., Trevisan, M. and Zawislak, P.A. (2011), "Management and innovation technological capability's predictor variables", Journal of Technology Management and Innovation, Vol. 6 No. 1.

Rohrbeck, R. and Gemünden, H.G. (2011), "Corporate foresight: Its three roles in enhancing the innovation capacity of a firm", Technological Forecasting and Social Change, Vol. 78 No. 2, pp. 231-243, doi: 10.1016/j.techfore.2010.06.019. 
Rothaermel, F.T. and Hess, A.M. (2010), "Innovation strategies combined", MIT Sloan Management Review, Vol. 51 No. 3, pp. 13-15.

Rupietta, C. and Backes-Gellner, U. (2019), "Combining knowledge stock and knowledge flow to generate superior incremental innovation performance - evidence from swiss manufacturing", Journal of Business Research, Vol. 94, pp. 209-222, doi: 10.1016/j.jbusres.2017.04.003.

Santoro, G., Vrontis, D., Thrassou, A. and Dezi, L. (2018), “The internet of things: building a knowledge management system for open innovation and knowledge management capacity", Technological Forecasting and Social Change, Vol. 136, pp. 347-354, doi: 10.1016/j.techfore.2017.02.034.

Sarros, J.C., Cooper, B.K. and Santora, J.C. (2008), "Through transformational leadership and organizational culture", Journal of Leadership and Organizational Studies, Vol. 15 No. 2, pp. 145-158, doi: 10.1177/1548051808324100.

Saunila, M. (2017), "Managing continuous innovation through performance measurement", Competitiveness Review, Vol. 27 No. 2, pp. 179-190, doi: 10.1108/CR-03-2015-0014.

Saunila, M., Pekkola, S. and Ukko, J. (2014), "The relationship between innovation capability and performance: the moderating effect of measurement", International Journal of Productivity and Performance Management, Vol. 63 No. 2, pp. 234-249, doi: 10.1108/IJPPM-04-2013-0065.

Saunila, M. and Ukko, J. (2012), "A conceptual framework for the measurement of innovation capability and its effects", Baltic Journal of Management, Vol. 7 No. 4, pp. 355-375, doi: 10.1108/ 17465261211272139 .

Shahzad, F., Giu, G.Y. and Shahbaz, M. (2017), "Organizational culture and innovation performance in pakistan's software industry”, Technology in Society, Vol. 51, pp. 66-73, doi: 10.1016/j. techsoc.2017.08.002.

Shibin, K.T., Gunasekaran, A. and Dubey, R. (2017), "Explaining sustainable supply chain performance using a total interpretive structural modeling approach", Sustainable Production and Consumption, Vol. 12, pp. 104-118, doi: 10.1016/j.spc.2017.06.003.

Sindhwani, R. and Malhotra, V. (2017), "A framework to enhance agile manufacturing system", Benchmarking: An International Journal, Vol. 24 No. 2, pp. 467-487, doi: 10.1108/BIJ-09-2015-0092.

Stålberg, L. (2018), "Adapting to dynamic conditions through continuous innovation in manufacturing".

Steiber, A. (2014), The Google Model: Managing Continuous Innovation in a Rapidly Changing World, Springer. 10.1021/cen-v085n045.p003.

Steiber, A. and Alänge, S. (2013), "A corporate system for continuous innovation: the case of google inc”, European Journal of Innovation Management, Vol. 16 No. 2, pp. 243-264, doi: 10.1108/ 14601061311324566.

Sun, H., Wong, S.Y., Zhao, Y. and Yam, R. (2012), "A systematic model for assessing innovation competence of Hong Kong/China manufacturing companies: a case study", Journal of Engineering and Technology Management - Management, Vol. 29 No. 4, pp. 546-565, doi: 10.1016/j.jengtecman.2012.03.005.

Sunardi, O. and Saputra, J.K. (2016), "Implementasi digital factory pada industri manufaktur skala menengah: Studi pendahuluan”, Jurnal Manajemen Teknologi, Vol. 15 No. 3, pp. 224-238, doi: 10.12695/jmt.2016.15.3.2.

Sushil, A. (2017), "Modified ISM/TISM process with simultaneous transitivity checks for reducing direct pair comparisons", Global Journal of Flexible Systems Management, Vol. 18 No. 4, pp. 331-351, doi: 10.1007/s40171-017-0167-3.

Tahriri, F., Mousavi, M., Hozhabri Haghighi, S. and Zawiah Md Dawal, S. (2014), "The application of fuzzy delphi and fuzzy inference system in supplier ranking and selection", Journal of Industrial Engineering International, Vol. 10 No. 3, doi: doi: 10.1007/s40092-014-0066-6.

Tan, F.T.C., Tan, B. and Pan, S.L. (2016), "Developing a leading digital multi-sided platform: examining IT affordances and competitive actions in alibaba", Communications of the Association for Information Systems, Vol. 38 No. 1, pp. 738-760, doi: 10.17705/1CAIS.03836. 
Teece, D.J. (2007), "Explicating dynamic capabilities: the nature and microfoundations of (sustainable) enterprise performance", Strategic Management Journal, Vol. 28 No. 13, pp. 1319-1350, doi: 10.1002/smj.

Valmohammadi, C. and Dashti, S. (2016), "Using interpretive structural modeling and fuzzy analytical process to identify and prioritize the interactive barriers of e-commerce implementation", Information and Management, Vol. 53 No. 2, pp. 157-168, doi: 10.1016/j. im.2015.09.006.

Venkatesh, V.G., Rathi, S. and Patwa, S. (2015), "Analysis on supply chain risks in indian apparel retail chains and proposal of risk prioritization model using interpretive structural modeling", Journal of Retailing and Consumer Services, Vol. 26, pp. 153-167, doi: 10.1016/j.jretconser.2015.06.001.

Walsh, J.P., Lee, Y.N. and Nagaoka, S. (2016), "Openness and innovation in the US: collaboration form, idea generation and implementation”, Research Policy, Vol. 45 No. 8, pp. 1660-1671, doi: 10.1016/j. respol.2016.04.013.

Wang, C.L. and Ahmed, P.K. (2004), "The development and validation of the organisational innovativeness construct using confirmatory factor analysis", European Journal of Innovation Management, Vol. 7 No. 4, pp. 303-313, doi: 10.1108/14601060410565056.

Wang, C. and Hu, Q. (2017), "Knowledge sharing in supply chain networks: effects of collaborative innovation activities and capability on innovation performance", Technovation, Vols 94/95, November 2015, 102010, doi: 10.1016/j.technovation.2017.12.002.

Wang, C.H., Lu, I.Y. and Chen, C.B. (2008), "Evaluating firm technological innovation capability under uncertainty", Technovation, Vol. 28 No. 6, pp. 349-363, doi: 10.1016/j.technovation.2007.10.007.

Wei, L.Q. and Lau, C.M. (2010), "High performance work systems and performance: the role of adaptive capability”, Human Relations, Vol. 63 No. 10, pp. 1487-1511, doi: 10.1177/0018726709359720.

Wiwoho, G., Suroso, A. and Wulandari, S.Z. (2020), "The role of strategic leadership in increasing ethical practices among pharmaceutical organizations in Jordan", Management Science Letters, Vol. 10 No. 10, pp. 2371-2378, doi: 10.5267/j.msl.2020.2.027.

Wu, H., Chen, J. and Jiao, H. (2016), "Dynamic capabilities as a mediator linking international diversification and innovation performance of firms in an emerging economy", Journal of Business Research, Vol. 69 No. 8, pp. 2678-2686, doi: 10.1016/j.jbusres.2015.11.003.

Xiang, G. and Wu, Y. (2012), "Enterprise's sustainable innovation in China: practice and theoretical research", Chinese Management Studies, Vol. 6 No. 1, pp. 92-107, doi: 10.1108/ 17506141211213807.

Xie, Y., Xue, W., Li, L., Wang, A., Chen, Y., Zheng, Q., Wang, Y. and Li, X. (2018), "Leadership style and innovation atmosphere in enterprises: an empirical study", Technological Forecasting and Social Change, Vol. 135, pp. 257-265, doi: 10.1016/j.techfore.2018.05.017.

Xie, X.M., Zeng, S.X. and Tam, C.M. (2011), "Towards continuous innovation for regional high-tech industrial clusters", Innovation, Vol. 13 No. 3, pp. 361-375.

Yadav, D.K. and Barve, A. (2016), "Modeling post-disaster challenges of humanitarian supply chains: a TISM approach”, Global Journal of Flexible Systems Management, Vol. 17 No. 3, pp. 321-340, doi: 10.1007/s40171-016-0134-4.

Yusr, M.M., Mokhtar, S.S.M. and Othman, A.R. (2014), "The effect of tqm practices on technological innovation capabilities: applying on Malaysian manufacturing sector", International Journal for Quality Research, Vol. 8 No. 2, pp. 197-216.

Zeng, J., Zhang, W., Matsui, Y. and Zhao, X. (2017), "The impact of organizational context on hard and soft quality management and innovation performance", International Journal of Production Economics, Vol. 185, pp. 240-251, doi: 10.1016/j.jpe.2016.12.031.

Zhang, G. and Tang, C. (2017), "How could firm's internal R\&D collaboration bring more innovation?", Technological Forecasting and Social Change, Vol. 125, pp. 299-308, doi: 10.1016/j. techfore.2017.07.007. 


\section{Further reading}

Distanont, A. and Khongmalai, O. (2018), "The role of innovation in creating a competitive advantage", Kasetsart Journal of Social Sciences, Vol. 41 No. 1, pp. 15-21, doi: 10.1016/j.kjss.2018.07.009.

Ganter, A. and Hecker, A. (2013), "Deciphering antecedents of organizational innovation”, Journal of Business Research, Vol. 66 No. 5, pp. 575-584, doi: 10.1016/j.jbusres.2012.02.040.

Richtnér, A., Brattström, A., Frishammar, J., Björk, J. and Magnusson, M. (2017), "Creating better innovation measurement practices", September.

\section{About the authors}

Benny Lianto is an Assistant Professor at the Department of Industrial Engineering, University of Surabaya, Indonesia. He holds a B.Eng. Degree in Industrial Engineering from the University of Surabaya in 1992. He received a master's degree in Industrial engineering and management from Bandung Institute of Technology, Indonesia. He is now pursuing her doctoral degree at Universitas Indonesia (UI). His areas of interest are in the innovation strategy and technopreneurship. His main research area is on developing an organization to become an innovative organization in the digital era. Benny Lianto can be contacted at: benny.lianto@ui.ac.id

Muhammad Dachyar, $\mathrm{PhD}$ is a Professor at the Industrial Engineering Department, Universitas Indonesia (UI), Indonesia. He received $\mathrm{PhD}$ from Dept. of Industrial Engineering, Bogor Agricultural Institute, Indonesia. He received a master's degree from VUB Brussel, Belgium majoring in industrial location and development. His areas of interest are in management information system, service management, business process reengineering, project management and maintenance management information system. His research activities are carried out through an academic and consulting project.

Tresna Priyana Soemardi $\mathrm{PhD}$ is a Professor at the Mechanical Engineering Department, Universitas Indonesia (UI), Indonesia. He received $\mathrm{PhD}$ from Ecole Centrale de Paris-France majoring in applied mechanics and advanced composites materials. His areas of interest are in Applied mechanics and composite material, product design and development, product innovation and innovation strategy management. His research activities are carried out through an academic and consulting project. He also as Supervisor and Co-Supervisor for Magister and Doctorat Dissertation on Innovation and Strategic Management at Faculty of Business and Economics, Universitas Indonesia, Indonesia.

For instructions on how to order reprints of this article, please visit our website: www.emeraldgrouppublishing.com/licensing/reprints.htm Or contact us for further details: permissions@emeraldinsight.com 

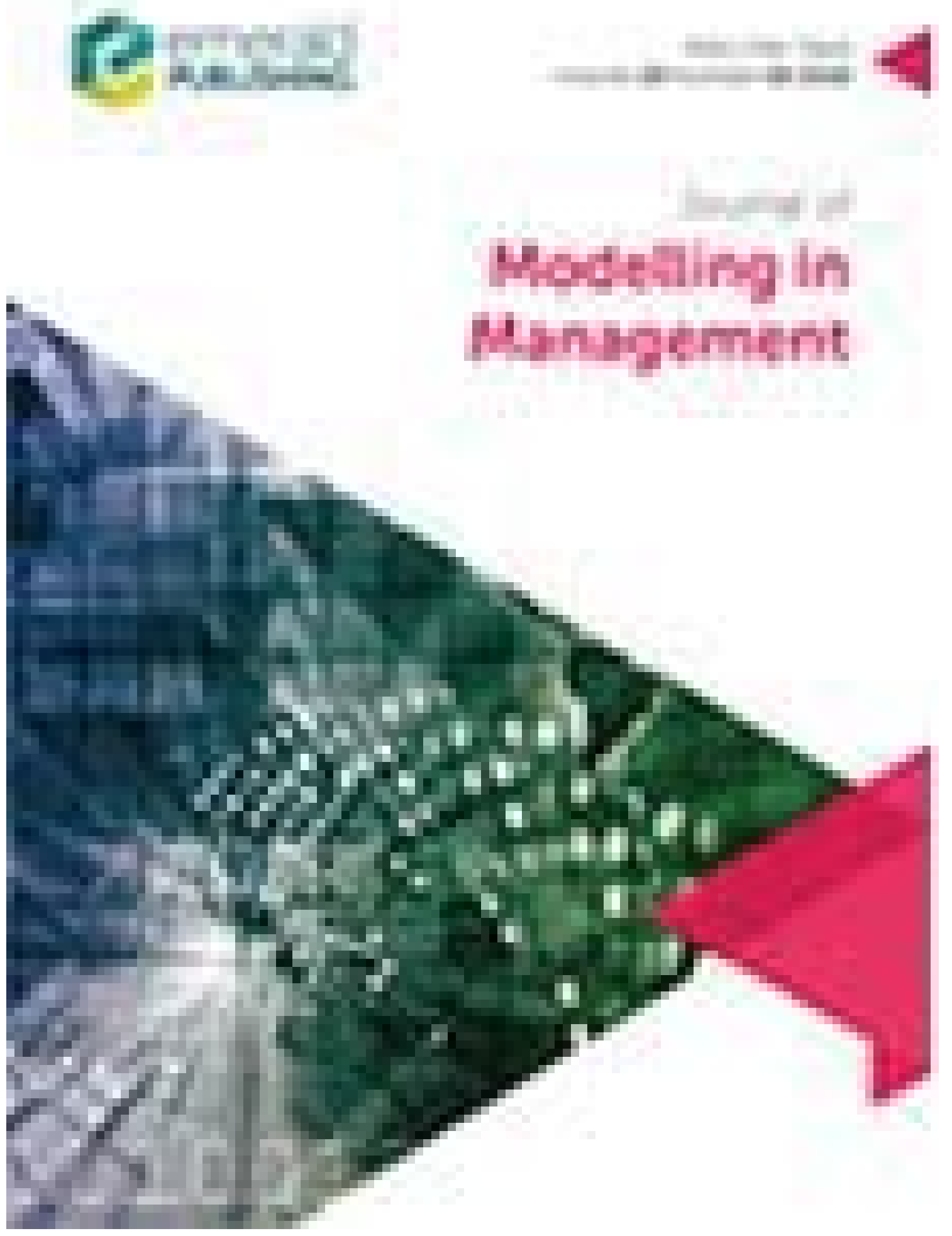
Viz Tools

\section{Journal of Modelling in Management}

\author{
COUNTRY \\ United Kingdom \\ Universities \\ Institutions in United Kingdom
}

Hindawi Open

Access Publishing

\section{Our Journals are Peer-Reviewed \& Open} Access. Publish With Us \& Reach a Wider Audience.

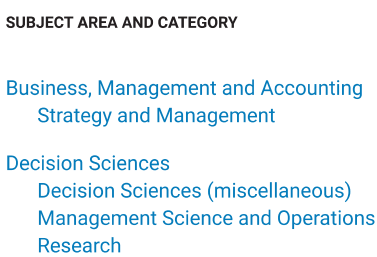

SUBJECT AREA AND CATEGORY

Business, Management and Accounting Strategy and Management

Decision Science

Decision Sciences (miscellaneous)

Management Science and Operations

Research

Hindawi Open

Access Publishing

Our Journals are Peer-Reviewed \& Open

Access. Publish With Us \& Reach a Wider

Audience.

Open
Enter Journal Title, ISSN or Publisher Name

(1) $\times$
PUBUSHER

H-INDEX

Emerald Group Publishing Ltd.

29
ISSN

17465664,17465672
COVERAGE

2006-2020
INFORMATION

Homepage

How to publish in this journal

huang@adelphi.edu 
SCOPE

Journal of Modelling in Management (JM2) provides a forum for academics and researchers with a strong interest in business and management modelling. The journal analyses the conceptual antecedents and theoretical underpinnings leading to research modelling processes which derive useful consequences in terms of management science, business and management implementation and applications. JM2 is focused on the utilization of management data, which is amenable to research modelling processes, and welcomes academic papers that not only encompass the whole research process (from conceptualization to managerial implications) but also make explicit the individual links between 'antecedents and modelling' (how to tackle certain problems) and 'modelling and consequences' (how to apply the models and draw appropriate conclusions). The journal is particularly interested in innovative methodological and statistical modelling processes and those models that result in clear and justified managerial decisions. JM2 specifically promotes and supports research writing, that engages in an academically rigorous manner, in areas related to research modelling such as: A priori theorizing conceptual models, Artificial intelligence, machine learning, Association rule mining. clustering, feature selection, Business analytics: Descriptive, Predictive, and Prescriptive Analytics, Causal analytics: structural equation modeling, partial least squares modeling, Computable general equilibrium models, Computer-based models, Data mining, data analytics with big data, Decision support systems and business intelligence, Econometric models, Fuzzy logic modeling, Generalized linear models, Multi-attribute decision-making models, Non-linear models, Optimization, Simulation models, Statistical decision models, Statistical inference making and probabilistic modeling. Text mining, web mining, and visual analytics, Uncertainty-based reasoning models.

Q Join the conversation about this journal

\section{S\&P Capital IQ Pro}

Industry defining data

dustrial Engineering and

Operations Research

Perspectives

NID

$67 \%$

similarity

\section{Management Systems}

KOR
Uncertain Supply Chain Management CAN

\section{OPSEARCH}

IND

\section{$62 \%$}

similarity options :

International Journal of Management and Decision GBR

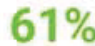

similarity 

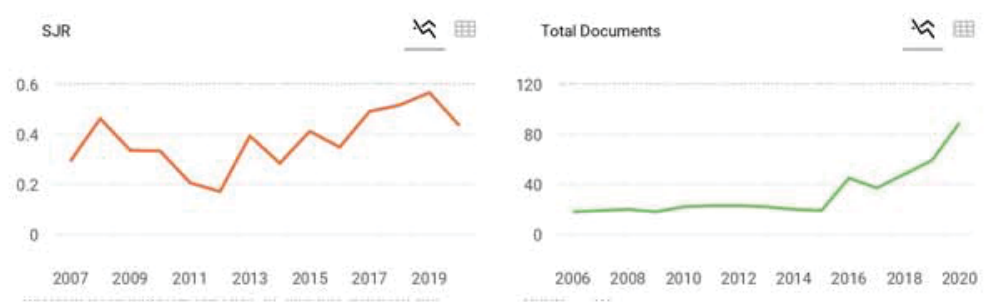

Total Cites Self-Cites 证

400

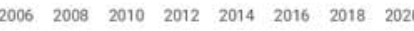
External Cites per Doc Cites per Doc 证 4

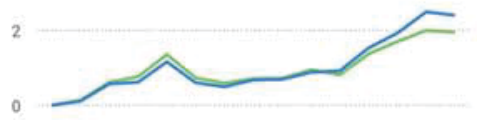
$\begin{array}{llllllll}2006 & 2008 & 2010 & 2012 & 2014 & 2016 & 2018 & 2020\end{array}$

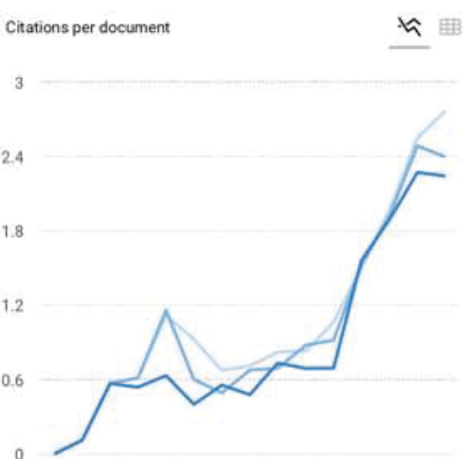

$\begin{array}{llllllll}2006 & 2008 & 2010 & 2012 & 2014 & 2016 & 2018 & 2020\end{array}$

Cites / Doc. ( 4 years)

Cites / Doc. (3 years)

- Cites / Doc. (2 years)
S International Collaboration th

20

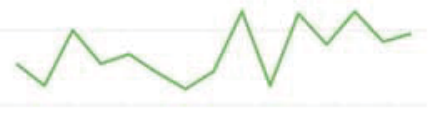

$\begin{array}{llllllll}2006 & 2008 & 2010 & 2012 & 2014 & 2016 & 2018 & 2020\end{array}$ Jurnal of Modelling in
Management

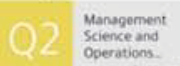

SIR 2020

0.43

Just copy the code below and paste within your htm code:

powered by scimagor con

<a href="https://www.scim

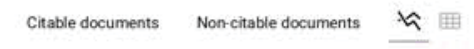

150

75

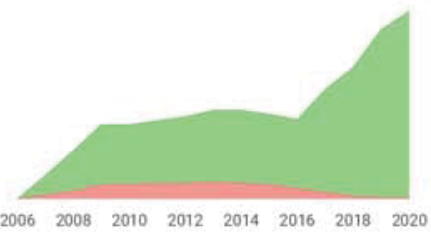

\section{G SClmago Graphica}

Explore, visually

communicate and make

sense of data with our new

free tool.

Get it

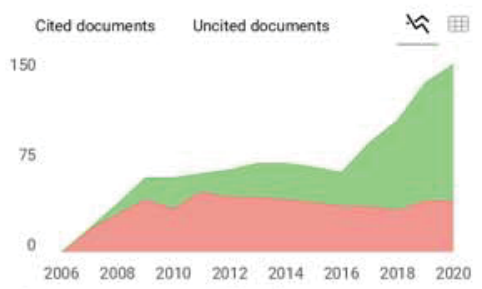

Metrics based on Scopus $\oplus$ data as of April 2021

Dear Ali, thank you very much for your comment. SCImago Journal and Country Rank uses Scopus data, our impact indicator is the SJR. Check out our web to localize the journal. We suggest you consult the Journal Citation Report for other indicators (like Impact Factor) with a Web of Science data source. Best Regards, SCImago Team 
I'm not a robot recaptorA

Submit

The users of Scimago Journal \& Country Rank have the possibility to dialogue through comments linked to a specific journal. The purpose is to have a forum in which general doubts about the processes of publication in the journal, experiences and other issues derived from the publication of papers are resolved. For topics on particular articles, maintain the dialogue through the usual channels with your editor.

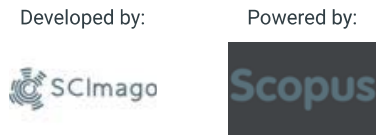

Follow us on @ScimagoJR

Scimago Lab, Copyright 2007-2020. Data Source: Scopus ${ }^{\circledR}$ 


\section{Source details}

\section{Journal of Modelling in Management}

Scopus coverage years: from 2006 to Present

Publisher: Emerald

ISSN: 1746-5664 E-ISSN: 1746-5672

Subject area: Business, Management and Accounting: Strategy and Management

Decision Sciences: Management Science and Operations Research Decision Sciences: General Decision Sciences

Source type: Journal

i Improved CiteScore methodology

CiteScore 2020 counts the citations received in 2017-2020 to articles, reviews, conference papers, book chapters and data papers published in 2017-2020, and divides this by the number of publications published in 2017-2020. Learn more $>$

CiteScore

2020

$2.8=\frac{594 \text { Citations } 2017-2020}{209 \text { Documents } 2017-2020}$

Calculated on 05 May, 2021
CiteScoreTracker 2021 (i)

$$
3.0=\frac{599 \text { Citations to date }}{200 \text { Documents to date }}
$$

\section{CiteScore rank 2020 (i)}

\begin{tabular}{lll} 
Category & Rank Percentile & \\
\hline Business, Management & & \\
and Accounting & $\# 174 / 440$ & 60th \\
\begin{tabular}{|l} 
Strategy and \\
Management
\end{tabular} & \\
$\begin{array}{l}\text { Decision Sciences } \\
L \text { Management } \\
\text { Science and } \\
\text { Operations Research }\end{array}$ & \\
\end{tabular}

View CiteScore methodology $>$ CiteScore FAQ $>$ Add CiteScore to your site $\mathbb{C}$ 

About Scopus
What is Scopus
Content coverage
Scopus blog
Scopus API
Privacy matters
日本語に切り替える
切换到简体中文
切換到繁體中文
Русский язык
Help
Contact us
ELSEVIER Terms and conditions $\pi$ Privacy policy $\pi$

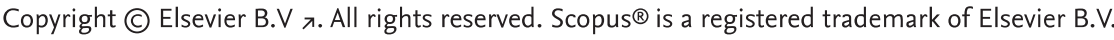
We use cookies to help provide and enhance our service and tailor content. By continuing, you agree to the use
Q RELX
of cookies. 


\section{Journal of Modelling in Management}

Issue(s) available: 53 - From Volume: 1 lssue: 1, to Volume: 16 Issue: 3

Subject: Management science \& operations > Management science/operations research

Subscribe to table of contents alerts (as) in RSS feed

\section{All issues EarlyCite}

Aspirations or survival: decision modeling and the effect of focus of attention in risky choice

Guy Moshe Ross

This research aims to test focus of attention effects in risky choice.

Strategic recommendations for financial technology service development: a comprehensive risk-benefit IPA-Kano analysis

Amalia Suzianti, Fannisa Rahma Haqqi, Safira Nurul Fathia

This study aims to purpose a strategy for Financial Technology (Fintech) service development to increase user adoption of Fintech services.

Modelling and analysis of factors for implementation of smart cities: TISM approach

The concept of "Smart Cities" is gaining prominence across the world as a solution to effectively address the issues or impediments faced by cities due to rapid.

Applications of artificial intelligence and machine learning within supply chains:systematic review and future research directions

Hassan Younis, Balan Sundarakani, Malek Alsharairi

The purpose of this study is to investigate how artificial imelligence (AI), as well as machine learning (ML) techniques, are being applied and implemented within supply...
A PDF (MO1 KE) 
Modelling exchange-driven fish price dynamics

PDF (472 KE)

Rui Xiang, Colin Jones, Rogemar Mamon, Marierose Chavez

This paper aims to put forward and compare two accessible approaches to model and forecast spot prices in the fishing industry. The first modelling approach is a...

Modeling the dynamical ethnic processes in multinational society

Gulim Tursyngaliyeva, Kakim Sagindykov, Assem Konyrkhanova, Rozamgul

i. PDF (2BS KE)

Nyazova, Ainur Sydykova

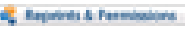

The problem of ethric conflicts and unrest is at the forefromt in a diverse world today.

This paper aims to identify ways of resolving social conflicts and establishing a

Predicting business processes of the social insurance using recurrent neural network and Markow chain

2. PDF $(777 \mathrm{KE})$

Mehrdad Fadaei PallehShahi, Sohrab Kordrostami, Amir Hossain Refahi Sheikhani, Marzieh Faridi Masouleh

Predicting the final status of an ongoing process or a subsequent activity in a process is an important aspect of process management. Semi-structured business processes...

Analysis of risk spillover effect of copper option in China

2. $\mathrm{PDF}(967 \mathrm{~KB})$

Wuyi Ye, Yiqi Wang, Jinhai Zneo

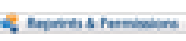

The purpose of this paper is to compare the changes in the risk spillover effects between the copper spot and futures markets before and after the issuance of copper_.

Non-radial two-stage network DEA model to estimate returns to scale

Seyed Mohamad Fakhr Mousavi, Alireza Amirteimoori, Sohrab Kordrostami,

1. PDF (GOS KE) Mohsen Vaez-Ghasemi

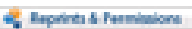

As returns to scale (RTS) describes the long run connection of the changes of outputs relative to increases in the inputs, the purpose of this study is to answer the...

Optimal pricing decisions for multichannel healthcare service with differing consemers' knowledge levels

Feng Yang Wei Wang, Xiabing Zheng

The purpose of this paper is to establish a stylized model to solve the pricing strategy, resource allocation and consumer surplus problems of multichannel healthcare services. i. PDF (6547 KB)

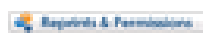


Post-purchase behaviour from customer perceived value of mobile payment services

Ming-Hsiung Hsiao

Mabile payment (MP), near field communication-based particularly, has become one of the future payment tools. This study aims to indicate the difference between consumer...

A scenario-based interval-input output model to analyze the risk of COVID-19 pandemic in port logistics

Bishal Dey Sarkar, Ravi Shankar, Arpan Kumar Kar

Presently, Indian sectors are manifesting a highter level of interdependency and making the economy more vulnerable to human-caused and natural disasters. COVID-19 pardemic...

An integrated framework for predicting the best financial performance of banks: evidence from Egypt

Mohamed El-Sayed Mousa, Mahmoud Abdelrahman Kamel

2. PDF (2.2 MAR

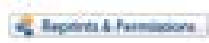

This study aims to develop and test a framework for integration between data enwelopmerM analysis (DCA) and artificial neural networks (ANN) to predict the best financial

A reliable location-inventory-routing three-echelon supply chain network under disruption risks

Ehsan Moheboan-Azad, Amir-Reza Abtahi, Reza Yousefi-Zenouz

This study aims to design a reliable multi-level, multi-product and multi-period locationinventary routing three-echelon supply chain network, which considers disruption...

On the relationship between policy uncertainty and sustainable investing Imlak Shaikh

In recent times, sustainable investment gaining much attention within the investors' community and it is broadly driven by environmental, social and governance (ISG.

2. PDF $1853 \mathrm{KEF}$

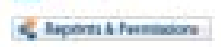

kituktaics 
Modelling the continuous innovation capability enablers in Indonesia's manufacturing industry

\section{Benny Lianto. Muhammad Dachyar, Tresna Prijana Soemardi}

The purpose of this paper is to identify and screen continuous innovation capability enablers (CICLS) in Indonesia's manufacturing sectors, develop a relationship among...

A methodology for structured literature network meta-analysis

Pachayaopan Murugaiyan, Venkatesakumar Ramakrishnan

Litule attention has been paid to restructuring existing massive amounts of literature data such that evidence based meaningful inferences and networks be drawn therefrom...

Scoring the financial distress and the financial statement frand of Garuda Indonesia with $\mathrm{DDCC} \times$ as the financial solutions

Ryan Aviantara

PT Garuda Indonesia (GIAA) Persero Tok is the one only pride airline of Indonesian

sovereignty. Alhough the bird achieved abundant international awards and...

Operations-based classification of the bullwhip effect

Sachin Gupta, Anurag Saxena

PDF 259 KE

6 Inperas fenterion

Present study deals with the most discussed rather than addressed yet still an unsolved problem of supply chain known as the bullwhip effect. Operational variables.

Ranking policing strategies as a function of criminal complaints: application of the PROMETHEE II method in the Brazilian context

Marcio Pereira Basilio, Vaidecy Pereira, Max Wriram Coeho de Oliveira, Antonio

Fernandes da Costa Neto

The puroose of this study is modeling of a problem of policing strategy order

using a multicriteria methoo
PDF 27 UAR

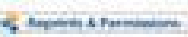

